\title{
International Trade and Macroeconomic Dynamics with Labor Market Frictions*
}

\author{
Matteo Cacciatore ${ }^{\dagger}$ \\ HEC Montréal
}

February 2012

\begin{abstract}
This paper studies how labor market frictions affect the consequences of trade integration in a two-country, stochastic, general equilibrium model of trade and macroeconomic dynamics with heterogeneous firms, endogenous producer entry, and frictional labor markets. The model successfully reproduces important empirical regularities that characterize trade integration both in the long run and over the business cycle. Two key results emerge. First, trade integration is always beneficial for welfare by inducing higher productivity, but unemployment can temporarily rise as trade barriers are lowered. Gains from trade are smaller in countries with more rigid labor markets, as production gradually shifts toward more flexible economies. Second, trade integration has important business cycle consequences. In contrast to traditional international business cycle models, but consistent with the data, the model correctly predicts that stronger trade linkages lead to increased business cycle synchronization. However, the strength of this effect and the consequences for output volatility depend on the labor market characteristics of integrating partners.
\end{abstract}

JEL Codes: E32, F16, F41, J60.

Keywords: trade integration, search and matching, firm entry, heterogeneous firms, business cycle comovement.

${ }^{*}$ I would like to thank Fabio Ghironi, James Anderson, Susanto Basu, Eyal Dvir, Giuseppe Fiori, Stefania Garretto, Francesco Giavazzi, Matteo Iacoviello, Federico Ravenna, Fabio Schiantarelli, Georg Strasser and Antonella Trigari for very valuable comments and suggestions. I also thank seminar participants at North Carolina State, Paris School of Economics, Bank of France, Bank of Italy, IMT Lucca, Williams College, University of Kansas, GRIPS-Tokyo, the Green Line Macro Meeting at Boston University. All errors are mine.

${ }^{\dagger}$ matteo.cacciatore@hec.ca. Address: Institute of Applied Economics, HEC Montréal, 3000, chemin de la Côte-Sainte-Catherine, Montréal (Québec), Canada H3T 2A7 


\section{Introduction}

In the public debate there has been significant concern about the effects of trade integration on labor market dynamics and, more generally, domestic, aggregate outcomes. The role played by labor market frictions has been central to the discussion since rigidities in the labor market have been considered detrimental to the outcomes of integration. In the academic literature, theoretical contributions have extensively studied the long-run effects of trade on unemployment, but little work has investigated how labor market frictions can affect outcomes of integration. This is the perspective of this paper, where the starting point is the documented evidence of substantial crosscountry heterogeneity in labor market characteristics and its importance for aggregate outcomes. ${ }^{1}$

To address the question, I build a two-country, stochastic, general equilibrium model of trade and macroeconomic dynamics with heterogeneous firms, endogenous producer entry, and frictional labor markets. I first show that the model is able to capture important empirical regularities that characterize trade integration in the long run and over the business cycle. Then I use the model to study the dynamic consequences of trade integration on unemployment and economic activity and the business cycle implications of stronger trade linkages between countries with potentially heterogeneous labor markets. This unified approach allows me to evaluate the full range of consequences of trade integration that are relevant for welfare.

The model builds on Ghironi and Melitz (2005) in its determination of trade along the dynamics of the economy: Heterogeneous, monopolistically competitive firms face sunk entry costs in the domestic market and both fixed and per-unit export costs. Relatively more productive firms export, while the remaining, less productive producers only serve the domestic market. The labor market is characterized by search and matching frictions as in Mortensen and Pissarides (1994), with costs of job creation and destruction and unemployment benefits that can differ across countries. Despite the presence of firm heterogeneity and idiosyncratic shocks to workers' productivity, model tractability is preserved since appropriately defined average productivities summarize all the relevant information for aggregate dynamics, as in the original Melitz (2003) model.

The key message of the paper is that labor market frictions play a decisive role for the outcomes

\footnotetext{
${ }^{1}$ The World Bank "Doing Business Report" (2007), following Botero, Djankov, Porta, and Lopez-De-Silanes (2004), constructed a measure of the rigidity of employment laws across countries. For example, the index for the U.S. is 97 - 100 indicating maximum flexibility - while the index for France, Italy and Germany it is 34,45 and 50 respectively. Moreover, labor market characteristics are found to be significant determinants of unemployment rates (Nickell, Nunziata, and Ochel (2005)), job flows (Haltiwanger, Scarpetta, and Schweiger (2008)), and the cyclical behavior of job creation and destruction (Gomez-Salvador, Messina, and Vallanti (2004) and Messina and Vallanti $(2007))$.
} 
of trade integration. Two main results emerge. First, trade is always beneficial for welfare by inducing higher productivity, but unemployment can temporarily rise as trade barriers are lowered and rigidities in the labor market substantially reduce gains from trade. ${ }^{2}$ Second, trade integration has important business cycle consequences. In contrast to benchmark international business cycle models, but consistent with the data, the model correctly predicts that stronger trade linkages lead to increased business cycle synchronization. However, the strength of this effect and the consequences for output volatility depend on the labor market characteristics of integrating partners.

The intuition for the results is straightforward. The combination of product and labor market dynamics explains observed responses to trade integration: reallocation of production toward most productive firms (Bernard et al., 2003, and Trefler, 2004) and within-industry job creation and destruction (Haltiwanger et al., 2004, and Levinsohn, 1999). ${ }^{3}$ In the new, long run equilibrium relatively less productive firms shrink, while relatively more productive ones expand. Productivity gains imply that the average return to a match increases, with beneficial effects for aggregate employment, output and consumption. Along the transition, however, unemployment can temporarily increase since stronger foreign competition results into destruction of low productive jobs and negative net producer entry. Even if trade is always beneficial for welfare, larger labor market frictions dampen job creation operated by most productive firms. Over time, the more flexible economy becomes a more profitable business environment, attracting more firms on the market. Employment and consumption increase by more than in the rigid trading partner both during the transition and in the new steady state.

Trade integration affects economic outcomes and welfare also through its impact on the domestic and international propagation of business cycle shocks. The model quantitatively matches the tradeinduced business cycles synchronization documented by Clark and van Wincoop (2001) and Frankel and Rose (1998). This result has often eluded international business cycle models that typically predict too small or negative effects of trade integration on output comovement - the so called trade-comovement puzzle identified by Kose and Yi (2001).

The interaction of product and labor market dynamics that determines the direct consequences

\footnotetext{
${ }^{2} \mathrm{~A}$ rigid labor market is characterized by higher costs of creating and destroying jobs together with larger unemployment benefits. For calibration purposes, I assume that the more rigid economy in the model features labor market characteristics similar to the Europe's Economic and Monetary Union (EMU) - Euro Area henceforth. The flexible economy represents the U.S. Hiring and firing restrictions and generosity of unemployment benefits are considered among the major contributors to the rigidity of continental European labor markets.

${ }^{3}$ While empirical work documented the presence of labor reallocation in response to trade integration between plants and within sectors, reallocation of workers across industries is found to be not significant (see Wacziarg and Wallack (2004)).
} 
of trade integration explains why the model is able to account for the observed business cycle synchronization. Aggregate productivity disturbances generate spikes in job creation and destruction, with persistent effects on employment as a consequence of matching frictions. The profitability of producer entry into domestic and export markets responds to aggregate labor market conditions, and the sluggish adjustment in the number of producers feeds back into employment dynamics. The amplification of domestic shocks induced by sunk entry costs and search and matching frictions implies that a reduction of barriers to trade results into larger and more persistent effects on foreign output dynamics. Moreover, the endogenous response of domestic and export market entry mitigates the terms of trade effects of shocks, reducing the cross-country reallocation of production over the business cycle. These two effects combine to generate variations in comovement that are in line with the data.

The mechanisms leading to increased synchronization do not depend on country-specific labor market features. Essential for the result is the endogenous interaction between product and labor market dynamics. However, as asymmetries in labor markets become less pronounced, comovement is further strengthened. Intuitively, heterogeneity in labor market characteristics affects the cyclical behavior of job creation and destruction, with consequences for entry and export dynamics. Volatility of aggregate fluctuations is lower in the more rigid economy, but output and unemployment display higher persistence, consistent with the empirical evidence. ${ }^{4}$ This asymmetric propagation of aggregate shocks across countries lowers the synchronization of business cycles following trade integration. ${ }^{5}$

The effects of stronger trade linkages on output volatility depend on the labor market characteristics of integrating partners. As comovement increases, economic fluctuations become larger in the economy with a more rigid labor market and reduce in the flexible one. Intuitively, with stronger trade linkages aggregate demand in the more rigid country becomes more volatile since the more flexible economy experiences more volatile fluctuations to begin with. When countries have symmetric labor markets, instead, output volatility moderately decreases everywhere. This result highlights the importance of heterogeneity in labor market frictions across integrating partners for

\footnotetext{
${ }^{4}$ Gomez-Salvador, Messina, and Vallanti (2004) and Messina and Vallanti (2007) find that job destruction is less responsive to shocks in countries with more stringent labor market regulation. Balakrishnan and Michelacci (2001) and Duval, Elmeskov, and Vogel (2007) document the larger persistence of employment and output dynamics in more rigid economies.

${ }^{5}$ This result has implications for the policy debates on economic integration and adoption of a common currency in the EMU. Frankel and Rose (1998) argued that lack of business cycle synchronization across countries should not necessarily be a concern when considering adoption of a common currency because the trade expansion from reduced trade frictions would result endogenously in increased comovement. The results of this paper show that this effect is stronger if trade integration is preceded by harmonization of labor market structures.
} 
the consequences of increased exposure to external shocks.

This paper is related to a recent literature in international macroeconomics that, starting with Ghironi and Melitz (2005), shows how models with richer trade microfoundations than usually assumed can yield novel insights into macroeconomic dynamics and contribute to explaining international business cycle evidence. ${ }^{6}$ I contribute to this literature by showing that labor market frictions play an important role for the endogenous propagation of shocks via trade. Moreover, the paper contributes to a recent literature that focuses on the business cycle implications of trade integration. For example, Arkolakis and Ramanarayanan (2009) build a model of aggregate fluctuations and vertical specialization in international trade, showing that stronger vertical trade linkages between countries can enhance the synchronization of business cycles. Drozdy and Nosal (2008) address the link between trade and comovement in a model with low short-run price elasticity of trade and high long-run elasticity. Differently from these papers, I focus on the role of labor market frictions in a model with endogenous product market dynamics.

The trade paper that is most closely related to my exercise is Helpman and Itskhoki (2010). ${ }^{7}$ As in that paper, I focus on the role of labor market imperfections for the consequences of trade integration. Helpman and Itskhoki introduce search unemployment in a static two-sector model of trade with heterogeneous firms to study the effects of labor market rigidities and trade impediments on long-run welfare, productivity, and unemployment. In contrast, I study the consequences of heterogeneity in labor market characteristics for the full range of effects of trade integration, including transition dynamics and business cycle fluctuations. ${ }^{8}$

The paper is also related to recent work that studied the dynamic adjustment to trade integration. Cosar (2011) develops a two-sector small open economy model with overlapping generations, labor market frictions, and sector-specific human capital. He compares the distributional and efficiency effects of alternative worker-assistance programs, focusing on workers' heterogeneity. I do not address distributional consequences of trade liberalization, but investigate the role of firm heterogeneity and labor market frictions for the dynamic adjustment to trade integration and its business cycle implications. ${ }^{9}$

\footnotetext{
${ }^{6}$ See, for instance, Bergin and Glick (2003), Contessi (2010), Corsetti, Martin, and Pesenti (2005), Lopez (2008) and Zlate (2010).

${ }^{7}$ Numerous papers have investigated the channels through which trade can affect long run unemployment abstracting from the role of country-specific labor market characteristics. See among others, Davidson, Martin, and Matusz (1999), Egger and Kreickemeier (2009), Felbermayr, Prat, and Schmerer (2011) and Matusz (1996).

${ }^{8}$ Furthermore, Helpman and Itskhoki disallow for forward-looking behavior of workers and firms on the labor market, which is a crucial feature of my model.

${ }^{9}$ Other papers that study the dynamic adjustment to trade integration abstracting from the role of labor market frictions and equilibrium unemployment are Alessandria and Choi (2011), Burstein and Melitz (2011), Costantini
} 
The rest of the paper is organized as follows. Section 2 presents the model. Section 3 discusses calibration and performance of the model in relation to the data. Section 4 analyzes steady-state and dynamic effects of trade integration. Sections 5 focuses on business cycle implications of stronger trade linkages. Section 6 concludes.

\section{The Model}

I model an economy that consists of two countries, Home and Foreign. Foreign variables are denoted with a superscript star. I focus on the Home economy in presenting the model, with the understanding that analogous equations hold for Foreign. All contracts and prices in the world economy are written in nominal terms and prices are flexible. ${ }^{10}$

Each economy is populated by a unit mass of atomistic households, where each household is thought of as an extended family with a continuum of members along the unit interval. In equilibrium, some family members are unemployed, while some others are employed. As common in the literature, I assume that family members perfectly insure each other against variation in labor income due to changes in employment status, so that there is no ex post heterogeneity across individuals in the household (see Andolfatto, 1996, and Merz, 1995).

\section{Household Preferences and Intratemporal Choices}

The representative household in the Home economy maximizes the expected intertemporal utility function $E_{0}\left\{\sum_{t=0}^{\infty} \beta^{t} C_{t}^{1-\gamma} /(1-\gamma)\right\}$, where $\beta \in(0,1)$ is the discount factor and $\gamma>0$ is the inverse of the intertemporal elasticity of substitution. The consumption basket $C_{t}$ is defined over a continuum $\Omega$ :

$$
C_{t}=\left(\int_{\omega \in \Omega} c_{t}(\omega)^{\frac{\theta-1}{\theta}} d \omega\right)^{\frac{\theta}{\theta-1}}
$$

where $\theta>1$ is the symmetric elasticity of substitution across goods. Following Ghironi and Melitz (2005), at any given point in time only a subset of goods $\Omega_{t} \in \Omega$ is available. Let $p_{t}(\omega)$ be the Home nominal price for the good $\omega \in \Omega_{t}$. The consumption-based price index for the Home economy is:

$$
P_{t}=\left(\int_{\omega \in \Omega} p_{t}(\omega)^{1-\theta} d \omega\right)^{\frac{1}{1-\theta}}
$$

and Melitz (2011), Dix-Carneiro (2011), Kambourov (2009). Moreover, all these contributions do not focus on the consequences of trade integration on business cycle fluctuations.

${ }^{10}$ For this reason I do not model demand for currency and resort to a cashless economy as in Woodford (2003). 


\section{Firms and the Labor Market}

In each country there is a continuum of monopolistically competitive firms, each producing a differentiated variety $\omega$ that can be sold domestically and abroad. Firms are heterogenous as they produce with different technologies indexed by relative productivity $z$. From now on, to save notation, I will abuse language by identifying a firm with its productivity $z$, omitting the variety index $\omega .^{11}$

The number of firm serving domestic and export market is endogenous, as in Ghironi and Melitz (2005). Prior to entry, firms are identical and face an entry cost $f_{e, t}$, to be specified later on. Upon entry, Home firms draw their productivity level $z$ from a common distribution $G(z)$ with support on $\left[z_{\min } ; \infty\right)$. Foreign firms draw their productivity level from an identical distribution. This relative productivity level remains fixed thereafter. There are no fixed costs of production. Hence, all firms that enter the economy produce in every period until they are hit by a "death" shock, which occurs with probability $\delta \in(0,1)$ in every period. Exporting is costly and it involves both a per-unit iceberg trade $\operatorname{cost} \tau_{t}>1\left(\tau_{t}^{*}>1\right)$ and a per-period fixed cost $f_{x, t}\left(f_{x, t}^{*}\right){ }^{12}$ To pay for $f_{x, t}$ each exporting firm needs to purchase a bundle of materials that has the same composition of the domestic consumption basket $C_{t}$.

Production requires only labor and it is characterized by constant returns to scale. I model labor market frictions within the context of a large firm set up, in order to allow both size and number of producing firms to vary in response to aggregate shocks. Each firm employs a continuum of workers. All incumbent firms are subject to aggregate and idiosyncratic productivity shocks. Within each firm the stock of labor varies because of the changes in hiring (job creation) and firing (job destruction). Denote with $Z_{t}$ the stochastic aggregate productivity, common to all firms. In addition, within each firm, there are idiosyncratic job specific productivity shocks. Those are i.i.d. draws from a time invariant distribution $H(a)$, with support $[0 ; \infty)$. Foreign workers draw their productivity level from an identical distribution.

Inside any firm $z$, the timing of hiring and firing proceeds as follows. At the start of the period, a fraction $\bar{\lambda}$ of last period's workers are exogenously separated from the firm. Aggregate shocks are

\footnotetext{
${ }^{11}$ In this continuum setting, the number of firms with a productivity $z$ is $g(z) d z$, the density at $z$. Formally, each of these firms has a different identity (each of them produces a unique differentiated variety $\omega$ ). However, as I will show later on, they all behave in the exact same way and so they are indistinguishable from their actions. For this reason I can safely omit the variety label $\omega$.

${ }^{12}$ There is substantial empirical evidence that a big portion of export costs are indeed sunk. The presence of sunk export costs would significantly complicate the model's solution. Qualitatively, the assumption of fixed rather than sunk export costs is harmless. Their quantitative relevance is left for further investigation.
} 
then realized, after which the firm posts a number $v_{z, t}$ of vacancies, incurring in a real cost $\kappa$ which is assumed to be independent of firm productivity $z$. The probability of finding a worker depends on a constant return to scale matching technology, which converts aggregate unemployed workers $U_{t}$ and aggregate vacancies $V_{t}$ into aggregate matches $M_{t}$ :

$$
M\left(U_{t}, V_{t}\right)=\chi U_{t}^{\varepsilon} V_{t}^{1-\varepsilon}, 0<\varepsilon<1
$$

Each firm meets unemployed workers at a rate $q_{t} \equiv M\left(U_{t}, V_{t}\right) / V_{t}$, while each unemployed worker meets a firm at a rate $p_{t} \equiv M\left(U_{t}, V_{t}\right) / U_{t}$. Following den Haan, Ramey, and Watson (2000) and Krause and Lubik (2007), I assume that newly created matches become immediately productive. For an individual firm, the inflow of new hires in $t$ is therefore $q_{t} v_{z, t}$, where $v_{z, t}$ is the number of vacancies posted by an incumbent with productivity $z$.

Once the hiring round has taken place, both newly hired and continuing workers receive an idiosyncratic productivity shock, $a$. Those workers whose idiosyncratic productivity falls below a certain reservation productivity $a_{z, t}^{c}$ (determined below) become unprofitable for the firm and their jobs are destroyed. When the firm dismisses a worker it has to incur a constant firing cost $F$, independent of $z \cdot{ }^{13}$ The endogenous, within-firm, job destruction rate is given by $H\left(a_{z, t}^{c}\right) \equiv \lambda_{z, t}$. The remaining workers start producing immediately. The law of motion of employment for the producer $z$ is therefore given by :

$$
l_{z, t}=\left(1-\lambda_{z, t}\right)\left[(1-\bar{\lambda}) l_{z, t-1}+q_{t} v_{z, t}\right]
$$

A worker with productivity $a$ employed in firm $z$ produces $z Z_{t} a$ units of output at time $t$. Firm output $y_{z, t}$ is determined by the measure $l_{z, t}$ of jobs, the firm specific productivity $z$, the aggregate productivity $Z_{t}$ and the average job productivity $\widetilde{a}_{z, t}$ :

$$
y_{z, t}=\int_{a_{z, t}}^{\infty} \frac{a}{1-H\left(a_{z, t}^{c}\right)} d H(a) z Z_{t} l_{z, t} \equiv \widetilde{a}_{z, t} z Z_{t} l_{z, t} .
$$

When a firm leaves the market, its entire stock of workers becomes unemployed, joining the

\footnotetext{
${ }^{13}$ In the model, firing costs are best interpreted as the cost of advance notice requirements and penalties due when terminating a redundant worker. Firing costs do not include severance payments from the firm to the worker. As shown by Mortensen and Pissarides (2003), severance transfers have no allocative effects when the wage is determined by Nash bargaining (as assumed below). Under this bargaining protocol, the components of the cost of firing a worker that represent a transfer from the firm to the worker leave the joint match surplus unaffected and therefore have no effect on job creation and job destruction.
} 
pool of searchers in the next period. I assume that there are no costs associated to the workers' layoff.

\section{Cost Minimization}

An incumbent with productivity $z$ minimizes the following cost function:

$$
E_{t}\left\{\sum_{s=0}^{\infty} \beta_{t, t+s}\left[\widetilde{w}_{z, s} l_{z, s}+\kappa v_{z, s}+\lambda_{z, t}\left[(1-\bar{\lambda}) l_{z, t-1}+q_{t} v_{z, t}\right] F\right]\right\}
$$

where $\beta_{t, t+1}=\beta(1-\delta)\left(C_{t+1} / C_{t}\right)^{-\gamma}$ is the household's discount factor adjusted for the exogenous exit probability and $\widetilde{w}_{z, t}$ is the average wage paid by the firm. Wages are not identical across workers as they depend on the idiosyncratic productivity of jobs. The second and third terms appearing in equation (3) reflect the cost of posting vacancies and firing workers, respectively. The two constraints in the cost minimization problem are given by equations (1) and (2). Denote with $\widetilde{\Gamma}_{z, t}$ and $\varphi_{z, t}$ the Lagrange multipliers attached to the two constraints. $\widetilde{\Gamma}_{z, t}$ represents the represents the average marginal value of employment for the producer $z$, while $\varphi_{z, t}$ is the real marginal cost. The first-order conditions for $v_{z, t}, l_{z, t}$ and $a_{z, t}^{c}$ imply:

$$
\begin{gathered}
\frac{\kappa}{q_{t}}=\left(1-\lambda_{z, t}\right) \widetilde{\Gamma}_{z, t}-\lambda_{z, t} F \\
\widetilde{\Gamma}_{z, t}=\varphi_{z, t} z Z_{t} \widetilde{a}_{z, t}-\widetilde{w}_{z, t}+(1-\bar{\lambda}) E_{t}\left\{\beta_{t, t+1}\left[\left(1-\lambda_{z, t+1}\right) \widetilde{\Gamma}_{z, t+1}-\lambda_{z, t+1} F\right]\right\}, \\
\varphi_{z, t} z Z_{t} a_{z, t}^{c}+(1-\bar{\lambda}) E_{t}\left\{\beta_{t, t+1}\left[\left(1-\lambda_{z, t+1}\right) \widetilde{\Gamma}_{z, t+1}-\lambda_{z, t+1} F\right]\right\}-F=w_{z, t}^{c},
\end{gathered}
$$

where $w_{z, t}^{c}$ is the real wage paid to the marginal worker with productivity $a_{z, t}^{c}$. Equation (4) states that the expected cost of filling a vacancy $-\kappa / q_{t}$ - must be equal to the expected benefit. ${ }^{14}$ Equation (5) states that the average value of a match, $\widetilde{\Gamma}_{z, t}$, is given by the marginal value product of the match plus its continuation value net of the wage bill. Equation (6) implies that, at the margin, the firm is indifferent between keeping or firing a worker with productivity $a_{z, t}^{c}$ : the value of the marginal match, which includes savings on firing costs and continuation value of the match, is equal to the wage paid to the worker.

\footnotetext{
${ }^{14}$ With probability $q_{t}$ the vacancy is filled, in which case two events are possible: either the new recruit is fired (which happens with probability $\lambda_{z, t}$ ) and the firm must pay the firing cost $F$, or the match survives the job destruction round, in which case the worker generates value for the firm.
} 
By substituting equations (4) and (6) into (5) I obtain the following job creation equation:

$$
\frac{\kappa}{q_{t}}=\left[\varphi_{z, t} z Z_{t}\left(\widetilde{a}_{z, t}-a_{z, t}^{c}\right)-\left(\bar{w}_{z, t}-w_{z, t}^{c}\right)\right]\left(1-\lambda_{z, t}\right)-F
$$

Combining equation (4) and (6), the job destruction equation becomes:

$$
\varphi_{z, t} z Z_{t} a_{z, t}^{c}+F+E_{t} \beta_{t, t+1} \frac{\kappa}{q_{t+1}}=w_{z, t}^{c} .
$$

The key difference between job creation and job destruction in the model is that vacancy posting is an intertemporal margin of employment adjustment, while separation is an intratemporal margin of adjustment.

The wage schedule is the solution of an individual Nash bargaining process which splits the surplus of the match between the firm and the worker. The analytical derivation of the wage equation is presented in Appendix A, here I report the equilibrium wage resulting from the bargaining between a worker with productivity $a$ and a producer with productivity $z$ :

$$
w_{z, t}(a)=(1-\eta)\left\{\varphi_{z, t} z Z_{t} a_{t}-(1-\bar{\lambda}) E_{t}\left(\beta_{t, t+1} F\right)\right\}+\eta \varpi_{t}
$$

where $\eta$ represents the firm bargaining share and $\varpi_{t}$ is the worker's outside option, defined as:

$$
\varpi_{t}=h_{p}+b+(1-\bar{\lambda}) E_{t}\left[\beta_{t, t+1} p_{t+1} \int_{z_{\min }}^{\infty}\left(\frac{v_{z, t+1}}{V_{t+1}} \widetilde{S}_{z, t+1}^{W}\right) d G(z)\right]
$$

As in standard search and matching models, the worker's outside option depend on current value of unemployment and the value of searching for other jobs. Current value of unemployment is given by home production, $h_{p}$, and unemployment benefits, $b$, a transfer from the government financed by lump sum taxes. The last term appearing in equation (10) represents the value of searching for other jobs. Notice that $\widetilde{S}_{z, t}^{W}$ is the average value of employment in a firm with productivity $z$ :

$$
\widetilde{S}_{z, t}^{W}=\int_{a_{z, t}^{c}}^{\infty}\left[w_{z, t}(a)-\varpi_{t}+(1-\bar{\lambda}) E_{t}\left(\beta_{t, t+1} \widetilde{S}_{z, t+1}^{W}\right)\right] d H(a)
$$

and $\left(p_{t} v_{z, t}\right) / V_{t}$ is the probability of a match with that producer when searching for jobs. ${ }^{15}$

\footnotetext{
${ }^{15}$ The worker's outside option $\varpi_{t}$ does not depend on firm productivity $z$ because the worker will be searching for jobs in any firm in the next period. Moreover, $\bar{\omega}_{t}$ does not depend on the current worker's productivity $a_{t}$ since the
} 
The average wage paid by the producer $z$ is an average of individual wages, weighted according to the distribution of the idiosyncratic productivities:

$$
\widetilde{w}_{z, t}=\int_{a_{z, t}^{c}}^{\infty}\left[w_{z, t}(a) \frac{d H(a)}{1-\lambda_{z, t}}\right]
$$

The average wage depends positively on the average value product of existing matches, the expected savings on firing costs and the size of workers' outside option.

\section{Profit Maximization}

I assume that the export price, $p_{x, t}(z)$, is denominated in the currency of export market. With flexible prices the law of one price holds, i.e. $p_{x, t}(z)=S_{t} p_{d, t}(z)$, where $S_{t}$ is the nominal exchange rate (units of Home currency per units of Foreign) and $p_{d, t}(z)$ is the domestic price of the good. The producer $z$ faces the following domestic and foreign demand for its output:

$$
\begin{aligned}
& y_{d, t}(z)=\left(\frac{p_{d, t}(z)}{P_{t}}\right)^{-\theta} Y_{t}^{C}, \\
& y_{x, t}(z)=\alpha\left(\frac{p_{x, t}(z)}{P_{t}^{*}}\right)^{-\theta} Y_{t}^{C *} .
\end{aligned}
$$

where $Y_{t}^{C}$ and $Y_{t}^{C *}$ denote aggregate demand at Home and abroad. Notice that aggregate demand in each country includes sources other than household consumption but it takes the same CES form as the country's consumption basket, with the same elasticity of substitution $\theta>0$ across goods. This ensures that the consumption price index for the CES consumption aggregator is also the price index for aggregate demand of the final basket.

Let $\rho_{d, t}(z) \equiv p_{d, t}(z) / P_{t}$ and $\rho_{x, t}(z) \equiv p_{x, t}(z) / P_{t}^{*}$ be the price of domestic and export Home goods relative to the price index in the destination market. Profit maximization implies that firms set fully flexible prices that reflects the same proportional markup $\theta /(\theta-1)$ over the real marginal $\operatorname{cost} \varphi_{z, t}$ :

$$
\rho_{d, t}(z)=\frac{\theta}{\theta-1} \varphi_{z, t}, \quad \rho_{x, t}(z)=\frac{\tau_{t}}{Q_{t}} \rho_{d, t}(z)
$$

where $Q_{t} \equiv S P_{t}^{*} / P_{t}$ is the consumption-based real exchange rate (units of Home consumption per units of Foreign).

Due to the presence of fixed export costs a firm may decide not to export in any given period worker's productivity in $t+1$ is not correlated with $a_{t}$. 
since expected profits cannot cover $f_{x, t}$. When making this decision a firm decomposes its total real profit $d_{t}(z)$ into portions earned from domestic sales, $d_{d, t}(z)$, and from potential export sales, $d_{x, t}(z)$. All these profits are expressed in units of the consumption basket in the firm's location. In the case of a Home firm, total profits at time $t$ are given by $d_{t}(z)=d_{d, t}(z)+d_{x, t}(z)$, where

$$
\begin{aligned}
& d_{d, t}(z)=\frac{1}{\theta} \rho_{d, t}(z) y_{d, t}(z) \\
& d_{x, t}(z)= \begin{cases}\frac{Q_{t}}{\theta} \rho_{x, t}(z) y_{x, t}(z)-f_{x, t} & \text { if firm } z \text { exports } \\
0 & \text { otherwise. }\end{cases}
\end{aligned}
$$

A firm will export if and only if the expected profit from exporting is non-negative. There exists a Home (Foreign) cut-off productivity $z_{x, t}\left(z_{x, t}^{*}\right)$ such that: $z_{x, t}=\inf \left\{z: d_{x, t}(z)>0\right\}$. I assume that the lower bound cost $z_{\min }$ is low enough to have $z_{x, t}\left(z_{x, t}^{*}\right)>z_{\min }$. This ensures the existence of an endogenously determined non-traded sector: firms with a productivity draw $z$ below $z_{x, t}\left(z_{x, t}^{*}\right)$ only produce for their domestic market in period $t$. The set of exporting firms fluctuates over time with changes in profitability of export.

\section{Aggregation and Productivity Parametrization}

As in Melitz (2003) and Ghironi and Melitz (2005), I define two special "average" productivity levels (proportional to the relative output shares): an average $\widetilde{z}_{d}$ for all producing firms that serve the domestic market and an average $\widetilde{z}_{x, t}$ for all Home exporters:

$$
\tilde{z}_{d}=\left[\int_{z_{\min }}^{\infty} z^{\theta-1} d G(z)\right]^{\frac{1}{\theta-1}}, \quad \tilde{z}_{x, t}=\left[\frac{1}{1-G\left(z_{x, t}\right)}\right]\left[\int_{z_{x, t}}^{\infty} z^{\theta-1} d G(z)\right]^{\frac{1}{\theta-1}}
$$

Analogous definitions hold in Foreign. ${ }^{16}$ Following Melitz (2003), I also define a weighted productivity average $\tilde{z}_{t}$ that reflects the combined market shares of all Home firms and the output

\footnotetext{
${ }^{16}$ Notice that, as in Ghironi and Melitz $(2005), \widetilde{z}_{d}=\widetilde{z}_{d}^{*}$ since all the producers in one country serve their domestic market. The export cut-offs $\widetilde{z}_{x, t}$ and $\widetilde{z}_{x, t}^{*}$ can instead differ across countries.
} 
shrinkage linked to exporting:

$$
\tilde{z}_{t}=\left\{\frac{1}{N_{d, t}}\left[\widetilde{z}_{d}^{\theta-1} N_{d, t}+\left(\frac{\widetilde{z}_{x, t}}{\tau}\right)^{\theta-1} N_{x, t}\right]\right\}^{\frac{1}{\theta-1}}
$$

where $N_{d, t}$ and $N_{x, t}$ are the number of firms that are producing for the domestic and export market, respectively. Melitz (2003) shows that these average productivity levels summarize all the information about productivity distributions relevant for macroeconomic variables. I show that Melitz's result still applies in a dynamic, stochastic model with search and matching frictions in the labor market. Melitz's aggregation survives since the firm's real marginal cost can still be written in the form $\varphi_{z, t}=\varphi_{t} / z$, where $\varphi_{t}$ (to be defined) is a component of the firm real marginal cost identical across plants. ${ }^{17}$ Since $\varphi_{z, t}=\varphi_{t} / z$, the real marginal cost is symmetric across plants up to firm-specific productivity differentials, as in as in Melitz (2003) and Ghironi and Melitz (2005). Therefore $z$ uniquely summarizes the impact of labor market frictions on the heterogenous plants' marginal costs. As shown in Appendix B, the result that $\varphi_{z, t}=\varphi_{t} / z$ is due to the fact that in the model heterogeneous producers all pay the same average wage and share the same marginal worker, regardless of their productivity level $z$. In other words, the within firm job destruction cut-off $a_{z, t}^{c}$ and the average wage $\widetilde{w}_{z, t}$ only depend on aggregate labor market variables, i.e. $a_{z, t}^{c}=a_{t}^{c}$ and $w_{z, t}=\widetilde{w}_{t}:$

$$
\widetilde{w}_{t}=(1-\eta)\left\{\varphi_{t} Z_{t} \widetilde{a}_{t}+(1-\bar{\lambda}) E_{t} \beta_{t, t+1}\left[1-(1-\bar{\lambda}) E_{t}\left(1-p_{t+1}\right) \beta_{t, t+1}\right] F\right\}+\eta\left(h_{p}+b\right)
$$

Essential for this result is the assumption that both firing and hiring costs do not depend on the firm productivity $z$. As long as $\kappa$ and $F$ are common across firms, the outside option of each producer — not being matched with a particular worker - is identical across producers and it only depends on aggregate labor market outcomes. ${ }^{18}$ The equilibrium values of $\varphi_{t}$ and $a_{t}^{c}$ are determined by the following two equations:

$$
\frac{\kappa}{q_{t}}=\eta \varphi_{t} Z_{t}\left(\widetilde{a}_{t}-a_{t}^{c}\right)\left(1-\lambda_{t}\right)-F
$$

\footnotetext{
${ }^{17}$ In Melitz (2003) and Ghironi and Melitz (2005) the labor market is Walrasian. Therefore, $\varphi_{t}=w_{t} / Z_{t}$.

${ }^{18}$ This assumption greatly simplifies the model solution. However, it does not undermine the ability of the model to account for aggregate labor market dynamics observed in the data (see below).
} 


$$
\eta \varphi_{t} Z_{t} a_{t}^{c}=\eta b+(1-\bar{\lambda}) E_{t} \beta_{t, t+1}\left[(1-\eta) \kappa \vartheta_{t+1}-\frac{\kappa}{q_{t+1}}\right]-\left[\eta+(1-\eta) E_{t} \beta_{t, t+1}\left(1-p_{t+1}\right)\right] F
$$

Since $\varphi_{z, t}=\varphi_{t} / z$ holds true for any productivity level $z$, it follows that $\varphi_{t}=\varphi_{\tilde{z}, t} \tilde{z}_{t}$. Put different, $\varphi_{t}$ also represents the effective average marginal cost of all the Home firms. Following Melitz (2003) and Ghironi and Melitz (2005), I can now restate the model in terms of average, representative firms. Define $\widetilde{l}_{t} \equiv l\left(\tilde{z}_{t}\right)$ the stock of labor of the average representative producer in the Home economy. From equation (1) it follows that:

$$
\widetilde{l}_{t}=\left(1-\lambda_{t}\right)\left[(1-\bar{\lambda}) \widetilde{l}_{t-1}+q_{t} \widetilde{v}_{t}\right]
$$

where $\widetilde{v}_{t} \equiv \widetilde{v}\left(\tilde{z}_{t}\right)$. The average per-firm stock of labor is such that:

$$
\widetilde{l}_{t}=\widetilde{l}_{d, t}+\frac{N_{x, t}}{N_{d, t}} \widetilde{l}_{x, t}
$$

where $\widetilde{l}_{d, t} \equiv l_{t}\left(\tilde{z}_{d}\right)=\widetilde{y}_{d, t} /\left(Z_{t} \widetilde{a}_{t} \tilde{z}_{d}\right)$ and $\widetilde{l}_{x, t} \equiv l_{t}\left(\tilde{z}_{x, t}\right)=\widetilde{y}_{x, t} \tau_{t} /\left(Z_{t} \widetilde{a}_{t} \widetilde{z}_{x, t}\right)$ are the workers producing domestic and export output. The average, relative price of domestic and export goods are, respectively, $\tilde{\rho}_{d, t} \equiv \rho_{d, t}\left(\tilde{z}_{d, t}\right)=[\theta /(\theta-1)] \varphi_{t} / \tilde{z}_{d}$ and $\tilde{\rho}_{x, t} \equiv \rho_{x, t}\left(\tilde{z}_{x, t}\right)=[\theta /(\theta-1)] \tau \varphi_{t} / Q_{t} \tilde{z}_{x, t}$. The average domestic profit is $\widetilde{d}_{d, t}=(1 / \theta) \widetilde{\rho}_{d, t} \widetilde{y}_{d, t}$, while the average export profit is $\widetilde{d}_{x, t}=(1 / \theta) \widetilde{\rho}_{x, t} \widetilde{y}_{x, t}-f_{x, t}$.

Following Melitz (2003) and Ghironi and Melitz (2005) I assume that $z$ is drawn from a Pareto distribution with lower bound $z_{\min }$ and shape parameter $k>(\theta-1) .{ }^{19}$ Under this assumption, the average productivities $\tilde{z}_{d}$ and $\tilde{z}_{x, t}$ become $\tilde{z}_{D}=\{k /[k-(\theta-1)]\}^{\frac{1}{\theta-1}}$ and $\tilde{z}_{x, t}=$ $\{k /[k-(\theta-1)]\}^{\frac{1}{\theta-1}} z_{x, t}$ The share of exporting firms is $N_{x, t} / N_{d, t}=1-G\left(z_{x, t}\right)=\left(z_{\min } / \tilde{z}_{x, t}\right)^{-k}\{k /[k-(\theta-1)]\}^{\frac{k}{\theta-}}$ Finally, the zero profit condition that determines the productivity cutoff $z_{x, t}$ satisfies $\tilde{d}_{x, t}=$ $k /[k-(\theta-1)] f_{x, t}$.

\section{Firm Entry and Exit}

In every period there is an unbounded mass of prospective entrants in both countries. Potential entrants are forward looking and correctly anticipate their future profits $d_{s}(z)$ in any period $s>t$ as well as the exogenous probability $\delta$ of incurring in the exit-inducing shock. Entrants at time $t$ will start producing only from $t+1$.

\footnotetext{
${ }^{19}$ The assumption of a Pareto distribution induces a size distribution of firms that is also Pareto.
} 
When entering the market, each producer has a stock of zero workers. I assume that each new entrants post vacancies immediately upon entry to build its stock of labor. In Appendix C I show that firms with a relative technology $z$ are all identical regardless of their timing of entry, i.e., they all have the same number of workers at any point in time and the sole difference among these firms is that they produce different varieties. It follows that upon entry new firms with productivity $z$ must post vacancies to match the size of incumbents that have the same productivity level $z$. As a result, the average representative producer entering at time $t$ posts $v_{d, t}^{E}=\widetilde{l}_{t} /\left[\left(1-\lambda_{t}\right) q_{t}\right]$ vacancies.

Prospective entrants compute their expected post-entry value - $\tilde{e}_{t}$ - defined as the present discounted value of the expected stream of per period profits $\widetilde{d}_{s}$ :

$$
\tilde{e}_{t}=E_{t}\left(\sum_{s=t+1}^{\infty} \beta_{s} \tilde{d}_{s}\right)
$$

Prior to entry, firms face a sunk entry cost $f_{e, t}$ to be paid in order to serve the market. This entry cost is made by two components: $f_{e, t}=f_{r, t}+\widetilde{l}_{t} /\left[\left(1-\lambda_{t}\right) q_{t}\right]$. The first term represents the real costs of regulation and technological requirements associated to product creation. Like the fixed export cost, $f_{r, t}$ is expressed in units of consumption. The second term appearing in equation (16) represents the cost of recruiting workers to start production. Entry occurs until firm value is equalized to the entry cost, leading to the following free entry condition:

$$
\tilde{e}_{t}=f_{e, t}
$$

Given the time to build assumption, the law of motion of firms is given by $N_{d, t}=(1-\delta)\left(N_{d, t-1}+\right.$ $\left.N_{e, t-1}\right)$. The number of producing firms represents the stock of capital of the economy. It behaves much like physical capital in a standard RBC model, but it has an endogenously fluctuating price given by (16). In particular, the key interaction between labor and product market dynamics is captured by the stock market price of investment $\widetilde{e}_{t}$ which summarizes the interdependence between product and labor market dynamics.

\section{Household Budget Constraint and First Stage Budgeting}

The representative household can invest in two types of assets: shares in mutual funds of firms and non-contingent bonds that are traded domestically and internationally. ${ }^{20}$ Investment in the mutual fund of firms in the stock market is the mechanism through which household savings are

\footnotetext{
${ }^{20}$ For simplicity, I assume extreme home bias in equity holdings and rule out international trade in firm shares.
} 
made available to prospective entrants to cover their entry costs. International assets markets are incomplete as only risk-free bonds are traded across countries. Home bonds, issued by Home households, are denominated in Home currency. Foreign bonds, issued by Foreign households, are denominated in Foreign currency.

Let $x_{t}$ be the share in the mutual fund of Home final-sector firms held by the representative household entering period $t$. The mutual fund pays a total profit in each period (in units of currency) that is equal to the total profit of all firms that produce in that period, $P_{t} N_{d, t} \widetilde{d}_{t}$, where $\widetilde{d}_{t}=\widetilde{d}_{d, t}+\frac{N_{x, t}}{N_{d, t}} \widetilde{d}_{x, t}$. During period $t$, the representative household buys $x_{t+1}$ shares in a mutual fund of $N_{d, t}+N_{e, t}$ firms (those already operating at time $t$ and the new entrants). Only a fraction $1-\delta$ of these firms will produce and pay dividends at time $t+1$. Since the household does not know which firms will be hit by the exogenous exit shock $\delta$ at the end of period $t$, it finances the continuing operation of all pre-existing firms and all new entrants during period $t$. The date $t$ price of a claim to the future profit stream of the mutual fund of $N_{d, t}+N_{e, t}$ firms is equal to the average nominal price of claims to future profits of Home firms, $P_{t} \widetilde{e}_{t}$.

Let $B_{t+1}$ and $B_{*, t+1}$ denote real holdings of Home and Foreign bonds respectively. ${ }^{21}$ To induce steady-state determinacy and stationary responses to temporary shocks in the model, I follow Turnovsky (1985) and assume a quadratic cost of adjusting bond holdings. The cost of adjusting Home bond holdings is $\xi\left(B_{t+1}\right)^{2} / 2$, while the cost of adjusting Foreign bond holdings is $\xi\left(B_{*, t+1}\right)^{2} / 2$. These cost are paid to financial intermediaries whose only function is to collect these transaction fees and rebate the revenue to households in lump-sum fashion in equilibrium.

The Home household's period budget constraint is:

$$
\begin{aligned}
& B_{t+1}+Q_{t} B_{*, t+1}+\frac{\xi}{2}\left(B_{t+1}\right)^{2}+\frac{\xi}{2} Q_{t}\left(B_{*, t+1}\right)^{2}+C_{t}+\widetilde{e}_{t}\left(N_{d, t}+N_{e, t}\right) x_{t+1}= \\
& =\left(1+r_{t}\right) B_{t}+\left(1+r_{t}^{*}\right) B_{*, t}+\left(\widetilde{d}_{t}+\widetilde{e}_{t}\right) N_{d, t} x_{t}+\widetilde{w}_{t} L_{t}+b\left(1-L_{t}\right)+T_{t}^{f}+T_{t}^{g} .
\end{aligned}
$$

where $r_{t+1}$ and $r_{t+1}^{*}$ are, respectively, the real interest rates on Home and Foreign bond holdings between $t$ and $t+1$, known with certainty as of $t$. Moreover, $b\left(1-L_{t}\right)$ represents aggregate unemployment benefits, $T_{t}^{g}$ are lump sum taxes from the government and $T_{t}^{f}$ is a lump-sum rebate of the cost of adjusting bond holdings from the intermediaries to which it is paid. The Euler

\footnotetext{
${ }^{21}$ Foreign holdings of home bonds are denoted with $B_{t}^{*}$, while Foreign holdings of foreign bonds are denoted by $B_{*, t}^{*}$.
} 
equations for bond holdings is:

$$
\begin{gathered}
C_{t}^{-\gamma}\left(1+\xi B_{t+1}\right)=\beta\left(1+r_{t+1}\right) E_{t}\left(C_{t+1}^{-\gamma}\right), \\
C_{t}^{-\gamma}\left(1+\xi B_{*, t+1}\right)=\beta\left(1+r_{t+1}^{*}\right) E_{t}\left(\frac{Q_{t+1}}{Q_{t}} C_{t+1}^{-\gamma}\right) .
\end{gathered}
$$

The Euler equations for share holdings is:

$$
\tilde{e}_{t}=\beta(1-\delta) E_{t}\left[\left(\frac{C_{t+1}}{C_{t}}\right)^{-\gamma}\left(\tilde{d}_{t+1}+\tilde{e}_{t+1}\right)\right]
$$

As expected, forward iteration of this equation and absence of speculative bubbles yield the expression for firm value used in the free entry condition above. ${ }^{22}$

\section{Equilibrium}

I can now characterize the equilibrium of the model. First, the welfare-based price index implies that:

$$
1=\widetilde{\rho}_{d, t}^{1-\theta} N_{d, t}+\widetilde{\rho}_{x, t}^{*^{1-\theta}} N_{x, t}^{*}
$$

Denote with $L_{t}$ the aggregate employment at the end of period $t . L_{t}$ is equal to the sum of total employment in domestic and export production plus the matches created by new entrants:

$$
L_{t}=\left(N_{d, t}+N_{e, t}\right)\left[\widetilde{l}_{d, t}+\frac{N_{x, t}}{N_{d, t}} \widetilde{l}_{x, t}\right]
$$

The number of unemployed workers searching for jobs at time $t$ is given by $U_{t}=1-(1-\delta)(1-\bar{\lambda}) L_{t}$, while total vacancies $V_{t}$ are the sum of the vacancies posted by incumbents and the vacancies posted by new entrants to build their stock of labor: $V_{t}=N_{d, t} \widetilde{v}_{t}+N_{e, t}\left[\widetilde{l}_{t} /\left(1-\lambda_{t}\right) q_{t}\right]$.

Aggregate demand in the domestic market is given by:

$$
Y_{t}^{C}=C_{t}^{M}+N_{e, t} f_{e, t}+N_{x, t} f_{x, t}+\kappa V_{t}
$$

where $C_{t}^{M}=C_{t}-h_{p}\left(1-L_{t}\right)$ represent market consumption, i.e. total consumption net of home production.

Bonds are in zero net supply, which implies the equilibrium conditions $B_{t+1}+B_{t+1}^{*}=0$ and

\footnotetext{
${ }^{22}$ I omit the transversality conditions that must be satisfied to ensure optimality.
} 
$B_{*, t+1}+B_{*, t+1}^{*}=0$ in all periods. Home net foreign assets are determined by:

$$
B_{t+1}=\left(1+r_{t}\right) B_{t}+Q_{t}\left(1+r_{t}^{*}\right) B_{*, t}+N_{x, t} \rho_{d, t} y_{x, t}-N_{x, t}^{*} Q_{t} \rho_{d, t}^{*} y_{x, t}^{*}
$$

The change in net foreign assets between $t$ and $t+1$ is determined by the current account:

$$
B_{t+1}-B_{t}=C A_{t} \equiv r_{t} B_{t}+Q_{t} r_{t}^{*} B_{*, t}+T B_{t}
$$

where $T B_{t}$ is the trade balance: $T B_{t} \equiv N_{x, t} \rho_{d, t} y_{x, t}-N_{x, t}^{*} Q_{t} \rho_{d, t}^{*} y_{x, t}^{*}$.

\section{Calibration and Model Properties}

\section{Calibration}

I interpret periods as quarters and calibrate the model to match selected targets of the U.S. economy in the period 1954:1-1980:1. ${ }^{23}$ I set the discount factor $\beta$ to 0.99, implying an annual real interest rate of 4 percent. The value of the risk aversion coefficient $\gamma$ is equal to 2. As in Ghironi and Melitz (2005) the elasticity of substitution across product varieties $\theta$ is set to 3.8 following Bernard, Eaton, Jensen, and Kortum (2003), who find that this value fits U.S. plant and macro trade data. Also following Ghironi and Melitz (2005) I set $k=3.4$, normalize $z_{\min }$ to 1 and calibrate the fixed export cost $f_{x}$ to match the share of exporting plants, equal to 21 percent. I set $\tau=1.8$ so that total trade (imports plus exports) over GDP is equal to 12 percent, the average value observed in the sample period. ${ }^{24}$ To calibrate the entry costs related to product market regulation, I follow Ebell and Haefke (2009) and set $f_{r}$ so that regulation costs amount to 5.2 months of per capita output.

I set the elasticity of the matching function $\varepsilon$ equal to 0.5 , consistent with Blanchard and Diamond (1989), and $\eta=\varepsilon$, so that the Hosios conditions is satisfied. To calibrate the exogenous within firm separation, $\bar{\lambda}$, and the exogenous exit of plants, $\delta$, I target the portion of job destruction due to the exit of plants and the overall job destruction due to endogenous separation. Davis, Haltiwanger, and Schuh (1996) report that the portion of job destruction due to plant exit is 20 percent in the U.S. Following den Haan, Ramey, and Watson (2000), I assume that 32 percent of job destruction is due to endogenous separation. I set unemployment benefits, $b$, so that the replacement rate, $b / w$, is equal to 0.54 , as reported by OECD (2004). Firing costs are set to zero.

\footnotetext{
${ }^{23}$ I calibrate the model to match U.S. macroeconomic data before trade integration. The sample splitting is quite arbitrary but none of the result is sensitive to this choice.

${ }^{24}$ This value is in line with the estimates of trade costs reported by Anderson and van Wincoop (2003).
} 
As common practice in the literature, I calibrate the cost of vacancy posting $\kappa$, home production, $h_{P}$, and matching efficiency, $\chi$, to match unemployment rate, probability of filling a vacancy and total separation rate in steady state. The unemployment rate is 5.5 percent, computed from quarterly data on U.S. unemployment. Total steady-state separation, $\lambda^{\text {tot }}=1-(1-\lambda)(1-$ $\bar{\lambda})(1-\delta)$, is 5.5 percent, as reported by Davis, Haltiwanger, and Schuh (1996). The probability of filling a vacancy is 70 percent, as reported by Fujita and Ramey (2007).

Following den Haan, Ramey, and Watson (2000), I assume that the idiosyncratic, job-specific productivity shocks are lognormally distributed with zero mean and standard deviation $\sigma_{A}$ chosen to match the volatility of employment relative to GDP. For the bivariate productivity process, I set persistence, spillover parameters and covariance of innovations consistent with evidence in Baxter (1995) and Baxter and Farr (2005), implying zero spillovers across countries, persistence equal to 0.999 and covariance equal to 0.259. I refer to this as Baxter calibration below. I perform sensitivity analysis by considering also values in Backus, Kehoe, and Kydland (1992) (BKK calibration below), with lower persistence (0.906) and positive spillovers (0.088). The benchmark, symmetric, calibration is summarized in Table 2 .

To introduce heterogeneity in labor market characteristics I assume that a rigid country features higher costs of hiring and firing workers, together with larger unemployment benefits. The target is the Euro Area. ${ }^{25}$. Following Thomas and Zanetti (2008) I assume that firing costs $F$ amount to 20 percent of the average steady state wage. Unemployment benefits are 60 percent of the average wage, as reported by OECD (2004). The cost of posting vacancies is calibrated so that the steady state unemployment rate is 8.3 percent. This implies that vacancy costs are 30 percent higher in the more rigid economy, a value in line with the evidence provided by the World Bank "Doing Business Report" (2007). ${ }^{26}$ All the other parameters are identical across countries, including the bivariate productivity process and the variance-covariance matrix of productivity innovations.

\footnotetext{
${ }^{25}$ The choice of the Euro Area as a benchmark rigid trading partner is quite natural since the model abstracts from cross country asymmetries in factor endowments (which can be assumed to be similar across the two economies). Moreover, Botero, Djankov, Porta, and Lopez-De-Silanes (2004) and OECD (2004) report substantial differences in terms of labor market characteristics between the U.S. and the Euro Area.

${ }^{26}$ In the rigid labor market the cutoff of workers' productivity, $a^{c}$, is lower than in the more flexible economy (due to the presence of firing costs). This implies that $\lambda^{t o t}=0.037$, i.e. steady state separation and job flows are lower compared to the flexible economy. The implied value for $\lambda^{\text {tot }}$ is remarkably close to what observed in countries belonging to the Euro Area (see Christoffel, Kuester, and Linzert (2009)).
} 


\section{Model Properties}

\section{Symmetric Labor Markets}

Since the purpose of the paper is to provide a quantitative assessment of the role of labor market frictions for the consequences of trade integration, I validate the model by testing its ability to reproduce the cyclical behavior of key macroeconomic variables in the U.S. (long-run targets are matched by construction because of the calibration startegy).

Figure 1 shows the impulse responses to a one-percent innovation to Home productivity when countries have symmetric, flexible, labor markets. Higher productivity increases profitability of existing matches at Home, incumbents post more vacancies and reduce job destruction, $j d_{t} \equiv$

$\lambda_{t}\left[\widetilde{l}_{t} /\left(1-\lambda_{t}\right)\right]\left(N_{d, t}+N_{e, t}\right)$. The larger present discounted value of future profits generates higher expected return to product creation, stimulating producer entry and investment $\left(I_{t} \equiv N_{E, t} e_{t}\right)$ at Home. Employment and GDP $\left(Y_{t} \equiv \widetilde{w}_{t} L_{t}+N_{d, t} \widetilde{d}_{t} t\right)$ increase. The number of producers able to cover the fixed export cost $f_{x, t}$ also rises, further boosting job creation, $j c_{t} \equiv q_{t} \widetilde{v}_{t} N_{d, t}+\widetilde{l}_{t} /\left(1-\lambda_{t}\right) N_{e, t}$. Employment and GDP increase in Foreign, implying positive comovement across the two economies. There are two mechanisms at work. First, aggregate demand at Home increases for all existing goods, domestic and foreign ones. Producers abroad anticipate that the increase in demand for their products will persist in the future: The expected profitability of existing and future matches rises, more vacancies are posted and to more low productive workers survive to job destruction. Second, endogenous producer entry and firm heterogeneity mitigate the depreciation of Home terms of trade (price of exports over price of imports, $Q_{t} \tilde{\rho}_{x, t} / \tilde{\rho}_{x, t}^{*}$ ). When new producers enter the market and recruit workers to begin production, the labor market becomes tighter: The average marginal cost of production increases for all the producer on the market because since the cost of filling a vacancy is higher due to congestion externalities. Moreover, the reduction in $\tilde{z}_{x, t}$ due to the selection of Home firms in the export market raises the average price of exported goods $\tilde{\rho}_{x, t}$, further weakening the Home terms of trade depreciation.

Home and Foreign positively co-move despite the presence of international trade in financial assets. The current account deficit run by the Home economy - domestic households borrow from abroad to finance entry of new firms - does not imply an asymmetric response of GDP across economies, differently from standard international real business cycle models.

Table 3 presents the model-implied, HP-filtered second moments under the Baxter calibration of the bivariate productivity process (normal fonts) and the alternative BKK calibration (italics). 
Bold fonts denote data moments. ${ }^{27}$ In the presence of endogenous producer entry and preferences that exhibit "love for variety", the variables measured in units of consumption do not have a direct counterpart in the data, i.e. they are not data-consistent. ${ }^{28}$ To resolve this issue, I follow Ghironi and Melitz (2005) and construct an average price index $\tilde{P}_{t}=\left(N_{d, t}+N_{x, t}^{*}\right)^{1-\theta} P_{t}$ that is the dataconsistent Consumer Price Index implied by the model. In turn, given any variable $X_{t}$ in units of consumption, its data-consistent counterpart is given by $X_{R, t} \equiv\left(X_{t} P_{t}\right) / \tilde{P}_{t}$.

The absolute standard deviations of aggregate output and the relative standard deviation of consumption and investment are close to the data. While employment volatility is matched by construction, the model correctly predicts that job destruction is more volatility than job creation, even though both are more volatile than in the data. The correlation between job creation and destruction and their contemporaneous correlations with output are very close to the data. With respect to the international business cycle, the cross-country correlations of output and employment are positive and comovement in consumption is smaller than comovement in GDP. These are significant improvements with respect to a standard international business cycles models. As explained, product and labor market frictions are crucial to generate these results.

I perform sensitivity analysis by considering also the BKK calibration of exogenous shocks. Table 3 shows that all results are unaffected with the exception of magnitude and ranking of crosscountry correlations in output and consumption correlations. Consumption is now more correlated than output. The result is entirely explained by the positive, and large, productivity spillover across countries. ${ }^{29}$

\section{Asymmetric Labor Markets}

Empirical work has shown that differences in labor market regulation affect domestic labor market fluctuations. For instance, Gomez-Salvador, Messina, and Vallanti (2004) and Messina and Vallanti (2007) documented that more stringent firing laws dampen the response of job destruction to the cycle, thus making job reallocation less counter-cyclical. Estimates for the US, Canada and the UK show that the increase in job destruction during economic downturns tends to be stronger than the increase in job creation during upturns, resulting in counter-cyclical movements in job reallocation.

\footnotetext{
${ }^{27}$ Data cover the period 1954:1-1980:1. Cross-country correlations are averages of bilateral correlations between the U.S. and Canada, Japan, West Germany and UK.

${ }^{28}$ See Ghironi and Melitz (2005) for a discussion.

${ }^{29} \mathrm{It}$ is important to notice, however, that the model generates a positive and sizable output comovement regardless of the productivity parametrization. Standard international business cycle models instead predict a negative or at best zero cross-country output correlation under the parametrization of Backus, Kehoe, and Kydland (1992). In those models, the resource-shifting motive has a first order effect over the cycle.
} 
The cyclical behavior of job reallocation is instead less clear for countries in Europe, where job reallocation tends to be acyclical or slightly procyclical.

Table 4 shows that the model is able to capture these stylized facts. In the rigid labor market firing costs make job destruction less volatile and job reallocation becomes more procyclical. The reduction of labor market flows over the business cycle translates into smaller output and employment volatility. Specifically, the standard deviation of output and employment are, respectively, 10 percent and 13 percent lower than in the flexible country. However, both GDP and employment are more persistent in the rigid economy, consistent with the evidence in Balakrishnan and Michelacci (2001) and Duval, Elmeskov, and Vogel (2007).

\section{Long-Run Effects and Adjustment to Trade Integration}

I begin the analysis about the consequences of trade integration by studying long-run effects and dynamic adjustment that follow reductions of trade costs. I consider a symmetric reduction of trade barriers $\tau$ and $\tau^{*}$, capturing a decrease in all the impediments to trade across countries. To pin down the change in trade costs I re-calibrate $\tau_{t}$ and $\tau_{t}^{*}$ so that in the new steady state the ratio of trade to GDP is 22 percent, the average value observed in the period $1980-2011$. The required reduction in trade costs is 22 percent. Throughout this section I abstract from the presence of aggregate uncertainty.

\section{Steady State Analysis}

The link between trade integration and labor market outcomes has been the primary focus of important contributions in the trade literature. ${ }^{30}$ Before discussing the general implications of increased trade linkages, it is worth investigating how openness to trade can affect equilibrium unemployment in a model featuring firm heterogeneity and endogenous job creation and destruction. Consider first the case in which countries have symmetric and flexible labor markets. ${ }^{31}$ In Appendix D I show that the steady-state unemployment rate is given by:

$$
U=\frac{\Lambda\left(a^{c}\right)}{\chi \vartheta_{t}^{1-\varepsilon}+\Lambda\left(a^{c}\right)},
$$

\footnotetext{
${ }^{30}$ Numerous papers have investigated the channels through which trade can affect long run unemployment abstracting from the role of country-specific labor market characteristics. See, among others, Davis and Harrigan (2007), Davidson, Martin, and Matusz (1999), Egger and Kreickemeier (2009), Felbermayr, Prat, and Schmerer (2011), Matusz (1996) and Helpman and Itskhoki (2010).

${ }^{31}$ For this reason $\mathrm{I}$ set $F=0$ in the following analysis.
} 
where $\Lambda\left(a^{c}\right)=\lambda^{t o t} /\left(1-\lambda^{t o t}\right)$. Changes in $a^{c}$ reflect variations in job flows, summarized by the reservation productivity $a^{c}$. The term $\chi \vartheta_{t}^{1-\varepsilon}$ in equation (20) corresponds instead to the inverse of unemployment duration $1 / p$. The effects of trade openness on equilibrium unemployment depend on the impact of $\tau$ on $\vartheta$ and $a^{c}$, i.e. on the relative shifts of job creation and job destruction. In steady state, equation (13) and (14) imply that:

$$
\begin{gathered}
\vartheta=\left[\frac{\eta \varphi Z\left(\widetilde{a}-a^{c}\right)(1-\lambda)}{\kappa}\right]^{\frac{1}{\varepsilon}}, \\
a^{c}=\frac{1}{\eta \varphi Z}\left\{\eta b+(1-\bar{\lambda})(1-\delta) \beta\left[(1-\eta) \kappa \vartheta-\kappa \vartheta^{-\varepsilon}\right]\right\} .
\end{gathered}
$$

In both equations it appears $\varphi$, the average marginal revenue of a match, and so we need to jointly determine how variations in $\tau$ affect $\varphi, \vartheta$ and $a^{c}$. In appendix D I show that:

$$
\varphi=\mu N_{d}^{\frac{1}{\theta-1}} \tilde{z}
$$

where $\mu=(\theta-1) / \theta$ is the inverse of gross markup. Equation (23) shows that $\varphi$ positively depends on the stock of varieties available to consumers, $N_{d}$, and average firm productivity $\tilde{z}$. The relation between $N_{d}$ and $\varphi$ captures a variety effect: When more products are available to consumers, the relative price of each individual good increases since the welfare-based price index falls as households derive more welfare from spending a given amount. As a result, the average marginal revenue of a match increases. The boost in average productivity $\tilde{z}$, instead, makes workers on average more productive, also increasing the average marginal revenue of a match. For any realistic parametrization of the model, trade openness always increases both $N_{d}$ and $\tilde{z} .{ }^{32}$

I can now discuss the implications of trade integration for the long-run unemployment rate. As $\varphi$ increases, equation (21) reveals that, other things equal, labor market tightness $\vartheta$ increases, lowering unemployment. Intuitively, the reduction in trade barriers implies that the cost of vacancy posting decreases relative to the productivity of the average firm and employers intensify recruitment efforts. From equation (22) we can also see that, ceteris paribus, the workers productivity cutoff $a^{c}$ falls

\footnotetext{
${ }^{32}$ As $\tau$ falls, the reallocation of market shares toward exporting firms is enough to generate an increase in average productivity, despite the absence of endogenous exit of least productive plants. Some among the most productive non-exporters begin to export and the market shares of the domestic producers shrink due to increased foreign competition. This implies that more efficient firms have a bigger weight in the definition of $\tilde{z}$. Even if the average productivity of exporters $\tilde{z}_{x}$ is falling after openness, the gain in market shares of new exporting firms is enough to guarantee that $\tilde{z}$ increases.
} 
in response to an increase in $\varphi$ : the average firm keeps a larger pool of relatively less productive workers because of the increased marginal revenue of existing matches. In general equilibrium, however, variations in $\vartheta$ and $a^{c}$ affect each other and the response of $\varphi$ cannot summarizes the effects of trade integration on long-run unemployment. ${ }^{33}$ A tighter labor market puts pressure on the aggregate wage and low productive matches become less attractive, potentially increasing $a^{c}$ and unemployment. Once again, for any realistic calibration $a^{c}$ always falls if countries have symmetric, flexible labor markets. More low productive matches survive in the new steady state and the overall flows into unemployment are reduced.

When countries have heterogeneous labor markets, equation (23) does not hold anymore. In this case we have that:

$$
\varphi=\mu N_{d}^{\frac{1}{\theta-1}} \tilde{z} \Phi
$$

where $\Phi=\left(1-\widetilde{\rho}_{x}^{*^{1-\theta}} N_{x}^{*}\right)^{\frac{1}{1-\theta}} \widetilde{z}_{d} / \tilde{z}$ is a term introduced by heterogeneity in labor market characteristics. The effects of trade integration on the average marginal revenue $\varphi$ now also depend on the response of Foreign export prices and Foreign exporters. In other words, the effects of trade on unemployment, mediated by the response of $\varphi$, now depends on cross-country differentials in average firm productivity.

A growing number of studies in the trade literature focuses on the long run relationship between trade integration and unemployment. Those contributions differentiate themselves with respect to the assumptions about the trade structure or the mechanisms leading to equilibrium unemployment. Papers focusing on the role of firm heterogeneity in presence of frictional unemployment yield different predictions. Helpman and Itskhoki (2010), the closest study to the present work, find that unemployment is not unambiguously lowered by trade openness. The symmetric version of their model can feature a negative trade-unemployment link under some parameterization. Differently from the present model, they assume a two country - two sector setup: trade boosts average productivity in the differentiated goods sector, making employment more attractive in that sector. This yields a reallocation of labor from the distortion-free numeraire sector into the friction-ridden differentiated good sector. Importantly, the impact of trade on unemployment operates only through the reallocation of labor across sectors, because sectoral unemployment rates do not change in their model in response to trade. Felbermayr, Prat, and Schmerer (2011) find instead a monotonic, negative long run relationship between trade integration and unemployment

\footnotetext{
${ }^{33}$ Absent endogenous job destruction it is possible to show that the increase in the marginal revenue of a match is a sufficient condition for unemployment to fall in response to trade integration.
} 
in a static trade model that abstract from endogenous job destruction.

Turning to the overall consequences of trade integration, Table 5 shows that when countries have symmetric labor markets, the long-run response of productivity, employment and aggregate welfare is positive. In particular, the model predicts that the increase in trade observed in the last twenty years raised aggregate welfare by 8 percent. At the same time, Table 5 shows that for the benchmark asymmetric calibration described in Section 2, employment increases everywhere and so does welfare. ${ }^{34}$ However, while gains from trade are always positive, the country with a more rigid labor market gains less then its flexible trading partner. The difference is sizable, as the rigid economy gives up 1.3 percent of long-run welfare.

To better understand the results about long-run effects of trade integration and the role of country-specific labor market frictions I now inspect the adjustment to the "integration shock" that leads to the new long-run equilibrium described above.

\section{Dynamic Adjustment}

In the context of the paper, trade integration is best interpreted as a reduction of all impediments to trade. Thus it seems more appropriate to assume that the integration shock consists in a gradual reduction of trade barriers over time. ${ }^{35}$ I assume that the reduction in trade costs gradually phases out in 15 years. Given the large size of the shock, I do not rely on approximation methods. Instead, exploiting the absence of aggregate uncertainty, I exactly solve the model using a Newton-type algorithm, first proposed by Laffargue (1990).

Figure 2 presents the dynamic adjustment when countries have symmetric, flexible labor markets. Consumption and aggregate welfare increase monotonically along the transition. ${ }^{36}$ Households reduce current savings to smooth consumption in anticipation of future productivity gains, immediately increasing $C$. Trade integration, however, triggers substantial gross job flows. As observed in the data (see Levinsohn (1999) and Haltiwanger, Kugler, Kugler, Micco, and Pages (2004)), import-competing, domestic employment, $l_{d, t}$, drops while employment in export activi-

\footnotetext{
${ }^{34}$ There exist parameterizations of the model for which long-run unemployment increases in the more rigid country. However, welfare effects are always positive as the more rigid economy still benefits because of positive terms of trade effects and increased availability of varieties to consumers.

${ }^{35}$ Transportation costs felt slowly through time. Moreover, a notable feature of many recent trade agreements is the gradual, rather than immediate, reduction of trade barriers. For example, European, Japanese and U.S. average tariffs have declined by over 90 percent since the first GATT round. These gradual reductions are partly attributable to deeper tariff cuts in successive GATT rounds. Many regional and bilateral agreements exhibit these same incremental reductions and well-detailed phase-in periods.

${ }^{36}$ Notice that part of the increase in consumption is due to variety effects. The data consistent consumption (measured by statistical agencies) still increases but to a much smaller extent.
} 
ties, $l_{x, t}$, rises. Unemployment and net producer entry are negatively affected in the initial phase of integration. Entry of producers falls because of fiercer competition from abroad (along the intensive margin), while selection of relatively more productive firms in the export market takes time. Moreover, the average producer in the economy find profitable to fire more of the relatively less productive workers, resulting in higher job destruction. These two effects combine, generating frictional unemployment. The pattern of adjustment in the labor market is consistent with the empirical evidence provided by Trefler (2004) for the Canada - U.S. Free Trade Agreement.

Figure 3 presents instead the dynamic adjustment to trade integration when countries have asymmetric labor market characteristics. Two key differences emerge. First, in the more rigid labor market domestic producers downsize more slowly compared to the flexible country. This is the case since firing costs dampen job destruction. At the same time, however, production gradually shifts toward the more flexible economy. Higher cost of creating jobs and larger unemployment benefits dampen incentives to create jobs in the more rigid country. Along the transition unemployment increases more in the rigid labor market and it reduces less in the long run.

As the dynamic adjustment described below will show, when countries become more integrated production shifts towards countries with more flexible labor markets, where the costs of creating and destroying jobs are lower. In other words, the flexible economy becomes a relatively more profitable business environment.

\section{Business Cycle Implications of Trade Integration}

A robust conclusion from empirical work is that, among industrialized economies, business cycles become more synchronized when trade linkages are stronger. In particular, by running cross country regressions, Frankel and Rose (1998) and Clark and van Wincoop (2001) find that countries with 3.5 times larger trade have a correlation that is 0.125 and 0.089 higher, respectively. Kose and Yi (2001) - reestimating the Frankel and Rose (1998) regression with updated data - find that a doubling of the median (across all country pairs) bilateral trade intensity is associated with an increase in the country pair's GDP correlation of about 0.06. I now study how stronger trade linkages impact on the domestic and international propagation of business cycle shocks. I first explore whether the model can account for the observed increase in comovement that follows trade integration and discuss the role of labor market frictions in this context. Then I analyze the model predictions for output volatility. 


\section{Output Comovement}

Table 6 shows that the model predicts an increase in output comovement of 30 percent when trade costs are reduced from 1.8 to 1.4. The absolute change in the cross-country GDP correlation is 0.10 . This number, however, is not readily comparable with the empirical evidence described above since the estimates reported by Frankel and Rose (1998), Clark and van Wincoop (2001) and Kose and Yi (2001) refer to the effects of increasing average bilateral trade volumes. The latter are smaller than the bilateral trade share implied by my initial calibration of trade costs. Table 6 presents results relative to the case in which the initial value of $\tau$ and $\tau^{*}$ is chosen to reproduce the average, bilateral trade share of the U.S. in the period $1954: 1980$. This value corresponds to 0.5 percent and it requires $\tau=2.5$. The change in trade cost is pinned to increase bilateral trade by a factor of 3.5, implying a 28 percent reduction of trade costs. In this case the model predicts that output comovement increases by $21 \%$, with an absolute change in GDP correlation of 0.06 percent, in line with the estimates of Frankel and Rose (1998).

The ability of the model to account for the synchronization observed in the data has often eluded standard international business cycle models that typically predict too small or negative comovement in response to trade integration - the so called trade-comovent puzzle. ${ }^{37}$ For example, Kose and Yi (2001) show that the Backus, Kehoe, and Kydland (1992) model augmented with transportation costs yields the counterfactual prediction of a smaller cross-country output correlation following reductions in trade costs. The reason is that in the benchmark model demand complementarities generated by reductions of trade barriers are too weak and the reallocation of production towards more productive locations over the cycle has a first order effect. Benchmark models lack of sufficient internal amplification and domestic shocks generate too small and short lasting effects on output fluctuations abroad.

The present model is able to match the observed increase in business cycle synchronization, and it does so in presence of financial integration across countries. The result is due to the joint presence of endogenous producer entry and labor market frictions. First, impulse responses presented in Section 3 highlighted the central role of product and labor market frictions for the domestic and international propagation of shocks. Aggregate disturbances generate spikes in job creation and destruction and employment remains persistently higher on account of matching frictions. Prof-

\footnotetext{
${ }^{37}$ This puzzle is distinct from the puzzles that Obstfeld and Rogoff (2001) document; in particular, it is different from the consumption correlation-puzzle. The trade-comovement puzzle is about the inability of the standard international RBC models to generate a strong change in output correlations from changes in bilateral trade intensity.
} 
itability of entry responds to aggregate labor market conditions and the sluggish adjustment in the number of producers on the market feeds back into employment dynamics magnifying the future output effects of the shock. As trade barriers are lowered, this amplification effect translates into larger and more persistent effects of domestic shocks on Foreign output dynamics. Intuitively, a given shock abroad has larger and more persistent effects on the present discounted value of a domestic match. At the same time, the domestic present discounted value of entry responds more strongly to Foreign aggregate conditions because of the larger share of export revenues in the average profit of domestic firms.

There is also a second mechanism at work in the model: endogenous entry and firm heterogeneity mitigates terms of trade effects of aggregate shocks. Therefore, reductions in trade barriers do not automatically amplify the importance of expenditure switching effects.

Table 6 shows that labor market characteristics of trading partners affect the intensity of the change in comovement, but they do not change the positive effect of trade on business cycle synchronization. Asymmetries in labor markets dampen the increase in output comovement. The reason is twofold. First, when trade opens up between countries with heterogeneous labor markets, there is an asymmetric propagation of external shocks which is absent if the economies are symmetry. Second, the resource shifting motive is stronger when countries have asymmetric labor markets. Lower trade barriers increase the incentives to shift resources towards the more flexible (rigid) economy in good (bad) times. During worldwide expansions households in the rigid economy invest abroad, attracted by the relatively higher returns in the flexible economy which exploits its greater ability to reallocate labor (reflected in higher profitability of entry). On the contrary, during worldwide downturns, incentives are reverted and resources tend to shift toward the more rigid economy which is somehow more protected in the aftermath of negative aggregate shocks as firing costs imply that employment and aggregate demand do not fall abruptly.

\section{Output Volatility}

The traditional arguments linking output volatility and trade refer either to the increased importance of external shocks or to changes in the degree of diversification of production across sectors. ${ }^{38}$ Indeed, while there is consensus about the relationship between trade and comovement, the empir-

\footnotetext{
${ }^{38}$ For instance, aggregate volatility could increase if production specializes in sectors characterized by more elastic product demand and factor supply as in Kraay and Ventura (2002) or in sectors characterized by higher idiosyncratic volatility Cuñat and Melitz (2007). At the same time, if trade changes the comovement properties of the trading sectors with the rest of the economy, volatility might decrease.
} 
ical relationship between trade and macroeconomic volatility is debated. For instance di Giovanni and Levchenko (2009) and Kose, Prasad, and Terrones (2003) find that trade openness increases output volatility (in particular in developing countries). Bejan (2006) and Cavallo (2007) document instead an opposite results.

This model highlights three other channels through which trade integration can affect the size of domestic fluctuations. First, firm heterogeneity and fixed export costs imply that a reduction of $\tau$ lowers the export productivity cutoff $z_{x}$. Under the Pareto parametrization, the density of firms with productivity $z_{x}$ is bigger and more producers are in the neighborhood of the marginal exporter. As a consequence, any given shock triggers a bigger variation in the number of exporting firms, which tends to increase output volatility.

Second as trade opens up, idiosyncratic, job-specific shocks are less important for aggregate fluctuations. As the average firm in the economy is larger and makes bigger profits a given shock triggers smaller variations in expected profits, reducing the sensitivity of job creation and destruction to aggregate disturbances. Smaller variations in job flows tend to reduce aggregate fluctuations.

Third, when countries have asymmetric labor market characteristics there are differences in the relative volatility of aggregate demand. Since the flexible economy is more responsive to shocks, stronger trade linkages imply that demand in the more rigid country becomes relatively more volatile. The more flexible economy experiences an opposite effect.

Table 6 shows that when countries are fully symmetric there is a moderate reduction of output volatility. With symmetric labor market characteristics, the mild decline in output volatility is explained by the reduction in profit volatility. When countries have asymmetric labor market characteristics the result changes. Volatility increases in the rigid country and it falls in the more flexible trading partners. Notice that the domestic country experiences a smaller reduction of output volatility compared to the increase that occurs in the rigid economy. Post integration, there is a shift of production toward the relatively more flexible economy: The importance of foreign demand fluctuations for domestic business cycles is smaller in the flexible economy compared to the more rigid one. The result is quite suggestive given that I have considered two large economies and assumed symmetry in the structure of exogenous shocks. If the more flexible trading partner were larger or it were characterized by more volatile shocks, the implications of relative differences in labor market characteristics could become even larger. 


\section{Conclusions}

I have developed a two country, stochastic, general equilibrium model of trade and macroeconomic dynamics with search and matching frictions in the labor market. I have used this model to study the effects of trade integration between countries with potentially heterogeneous labor market characteristics. In so doing, I contribute to the trade literature, which typically abstracts from the effects of stronger trade linkages on aggregate fluctuations, and the international macroeconomic literature, by exploring the role of labor market frictions and trade in explaining international business cycles.

The key message of the paper is that labor market frictions and their heterogeneity across trading partners play an important role for the short- to long-run effects of trade integration. The model predicts that more flexible labor markets are a source of competitive advantage following reductions of trade barriers and gains from trade are dampened in more rigid trading partners. Trade is beneficial for welfare at any point in time even if labor market outcomes can be negatively affected along the transitory adjustment. Business cycle implications of stronger trade linkages suggest that the trade expansion from reduced trade frictions increases comovement across countries. Results also indicate that this effect is stronger if trade integration is preceded by harmonization of labor market structures. The effect on output volatility depend on labor market characteristics of integrating partners.

From a theoretical point of view this paper makes two contributions. First, the model introduces a source of amplification and propagation of shocks not investigated before, as typical model of international business cycles assume Walrasian labor markets and they abstract from the endogenous determination of the number of firms serving domestic and foreign markets. The interaction between product and labor market dynamics in presence of sunk entry costs and search and matching frictions turns out to be very important in explaining the effects of stronger trade linkages across countries. Second, I have shown that the original Melitz (2003) aggregation procedure can be extended to a dynamic model featuring search and matching frictions in the labor markets with endogenous job creation and destruction.

The model abstracts from a number of important features which are left for future research. For example, the role of comparative advantage is ignored, as the focus is restricted to within industry trade. If trade promotes production specialization across countries, relative labor market characteristics might contribute to shape the nature of comparative advantage. As a consequence, 
there could be additional consequences for sectoral and aggregate unemployment and implications for business cycle dynamics not captured by a one sector model.

\section{References}

Alessandria, G., and H. Choi (2011): "Establishment heterogeneity, exporter dynamics, and the effects of trade liberalization," Discussion paper.

Anderson, J. E., And E. VAn Wincoop (2003): "Gravity with Gravitas: A Solution to the Border Puzzle," American Economic Review, 93(1), 170-192.

Arkolakis, C., and A. Ramanarayanan (2009): "Vertical Specialization and International Business Cycle Synchronization," Scandinavian Journal of Economics, 111(4), 655-680.

Backus, D. K., P. J. Kehoe, and F. E. Kydland (1992): "International Real Business Cycles," Journal of Political Economy, 100(4), 745-75.

Balakrishnan, R., and C. Michelacci (2001): "Unemployment dynamics across OECD countries," European Economic Review, 45(1), 135-165.

Baxter, M. (1995): "International Trade and Business Cycles," NBER Working Papers 5025, National Bureau of Economic Research, Inc.

Baxter, M., And D. D. FARr (2005): "Variable capital utilization and international business cycles," Journal of International Economics, 65(2), 335-347.

BeJAn, M. (2006): "Trade Openness and Output Volatility," MPRA Paper 2759, University Library of Munich, Germany.

Bentolila, S., and G. Bertola (1990): "Firing Costs and Labour Demand: How Bad Is Eurosclerosis?," Review of Economic Studies, 57(3), 381-402.

Bergin, P. R., and R. Glick (2003): "Endogenous Tradability and Macroeconomic Implications," NBER Working Papers 9739, National Bureau of Economic Research, Inc.

Bernard, A. B., J. Eaton, J. B. Jensen, and S. Kortum (2003): "Plants and Productivity in International Trade," American Economic Review, 93(4), 1268-1290. 
Blanchard, O., and P. Diamond (1989): “The Aggregate Matching Function," Working papers Massachusetts Institute of Technology (MIT), Department of Economics, (538).

Botero, J., S. Djankov, R. Porta, and F. C. Lopez-De-Silanes (2004): "The Regulation of Labor," The Quarterly Journal of Economics, 119(4), 1339-1382.

Burstein, A., and M. J. Melitz (2011): "Trade Liberalization and Firm Dynamics," NBER Working Papers 16960, National Bureau of Economic Research, Inc.

Cavallo, E. A. (2007): "Output Volatility and Openness to Trade: A Reassessment," RES Working Papers 4518, Inter-American Development Bank, Research Department.

Christoffel, K., K. Kuester, and T. Linzert (2009): "The role of labor markets for euro area monetary policy," European Economic Review, 53(8), 908-936.

Clark, T. E., and E. van Wincoop (2001): "Borders and business cycles," Journal of International Economics, 55(1), 59-85.

Contessi, S. (2010): "How does multinational production change international comovement?," Discussion paper.

Corsetti, G., P. Martin, and P. A. Pesenti (2005): "Productivity Spillovers, Terms of Trade and the \&quot;Home Market Effect\&quot;" NBER Working Papers 11165, National Bureau of Economic Research, Inc.

Cosar, A. K. (2011): “Adjusting to Trade Liberalization: Reallocation and Labor Market Policies," Working paper.

Costantini, J., And M. J. Melitz (2011): "The Dynamics of Firm-Level Adjustment to Trade Liberalization," in The organization of firms in a global Economy, ed. by D. M. . T. V. E. Helpman. Harvard University Press.

Cuñat, A., And M. J. Melitz (2007): "Volatility, Labor Market Flexibility, and the Pattern of Comparative Advantage," CEP Discussion Papers dp0799, Centre for Economic Performance, LSE.

Davidson, C., L. Martin, and S. Matusz (1999): "Trade and search generated unemployment," Journal of International Economics, 48(2), 271-299. 
Davis, D. R., and J. Harrigan (2007): “Good Jobs, Bad Jobs, and Trade Liberalization,” NBER Working Papers 13139, National Bureau of Economic Research, Inc.

Davis, S. J., J. Haltiwanger, and S. Schuh (1996): "Small Business and Job Creation: Dissecting the Myth and Reassessing the Facts," Small Business Economics, 8(4), 297-315.

den Haan, W. J., G. Ramey, and J. Watson (2000): "Job Destruction and Propagation of Shocks," American Economic Review, 90(3), 482-498.

Di Giovanni, J., And A. A. Levchenko (2009): "Trade Openness and Volatility," The Review of Economics and Statistics, 91(3), 558-585.

DiX-Carneiro, R. (2011): “Trade Liberalization and Labor Market Dynamics,” Working paper.

Drozdy, L. A., And J. B. Nosal (2008): "Long-Run Price Elasticity of Trade and the TradeComovement Puzzle," Working paper.

Duval, R., J. Elmeskov, and L. Vogel (2007): "Structural Policies and Economic Resilience to Shocks," OECD Economics Department Working Papers 567, OECD, Economics Department.

Ebell, M., and C. Haefke (2009): "Product Market Deregulation and the U.S. Employment Miracle," Review of Economic Dynamics, 12(3), 479-504.

Egger, H., and U. Kreickemeier (2009): "Firm Heterogeneity And The Labor Market Effects Of Trade Liberalization," International Economic Review, 50(1), 187-216.

Felbermayr, G., J. Prat, and H.-J. Schmerer (2011): "Globalization and labor market outcomes: Wage bargaining, search frictions, and firm heterogeneity," Journal of Economic Theory, 146(1), 39-73.

Frankel, J. A., and A. K. Rose (1998): "The Endogeneity of the Optimum Currency Area Criteria," Economic Journal, 108(449), 1009-25.

Fujita, S., ANd G. RAmey (2007): "Job matching and propagation," Journal of Economic Dynamics and Control, 31(11), 3671-3698.

Ghironi, F., and M. J. Melitz (2005): "International Trade and Macroeconomic Dynamics with Heterogeneous Firms," The Quarterly Journal of Economics, 120(3), 865-915. 
Gomez-Salvador, R., J. Messina, and G. Vallanti (2004): "Gross job flows and institutions in Europe," Labour Economics, 11(4), 469-485.

Haltiwanger, J., A. Kugler, M. Kugler, A. Micco, and C. Pages (2004): "Effects of tariffs and real exchange rates on job reallocation: evidence from Latin America," Journal of Policy Reform, 7(4), 191-208.

Haltiwanger, J., S. Scarpetta, and H. Schweiger (2008): "Assessing Job Flows Across Countries: The Role of Industry, Firm Size and Regulations," NBER Working Papers 13920, National Bureau of Economic Research, Inc.

Helpman, E., and O. Itskhoki (2010): "Labour Market Rigidities, Trade and Unemployment," Review of Economic Studies, 77(3), 1100-1137.

Kambourov, G. (2009): "Labour Market Regulations and the Sectoral Reallocation of Workers: The Case of Trade Reforms," Review of Economic Studies, 76(4), 1321-1358.

Kose, M. A., E. S. Prasad, and M. E. Terrones (2003): "How Does Globalization Affect the Synchronization of Business Cycles?," American Economic Review, 93(2), 57-62.

Kose, M. A., And K.-M. Yi (2001): "International Trade and Business Cycles: Is Vertical Specialization the Missing Link?," American Economic Review, 91(2), 371-375.

Kraay, A., and J. Ventura (2002): "Trade integration and risk sharing," European Economic Review, 46(6), 1023-1048.

Krause, M. U., And T. A. Lubik (2007): "The (ir)relevance of real wage rigidity in the New Keynesian model with search frictions," Journal of Monetary Economics, 54(3), 706-727.

LAffargue, J.-P. (1990): "Résolution d'un modèle macroéconomique avec anticipations rationnelles," Annales d'Economie et de Statistique, (17), 04.

Levinsohn, J. (1999): "Employment responses to international liberalization in Chile," Journal of International Economics, 47(2), 321-344.

Ljungqvist, L., And T. J. Sargent (2007): "Understanding European unemployment with a representative family model," Journal of Monetary Economics, 54(8), 2180-2204. 
Lopez, J. A. R. (2008): "Prices and Exchange Rates: A Theory of Disconnect," Working Papers 080902, University of California-Irvine, Department of Economics.

Matusz, S. J. (1996): "International Trade, the Division of Labor, and Unemployment," International Economic Review, 37(1), 71-84.

Melitz, M. J. (2003): "The Impact of Trade on Intra-Industry Reallocations and Aggregate Industry Productivity,” Econometrica, 71(6), 1695-1725.

Messina, J., and G. Vallanti (2007): "Job Flow Dynamics and Firing Restrictions: Evidence from Europe," Economic Journal, 117(521), 279-301.

Mortensen, D. T., and C. A. Pissarides (1994): "Job Creation and Job Destruction in the Theory of Unemployment," Review of Economic Studies, 61(3), 397-415.

Nickell, S., L. Nunziata, And W. Ochel (2005): "Unemployment in the OECD Since the 1960s. What Do We Know?," Economic Journal, 115(500), 1-27.

Obstfeld, M., and K. Rogoff (2001): "The Six Major Puzzles in International Macroeconomics: Is There a Common Cause?," in NBER Macroeconomics Annual 2000, Volume 15, NBER Chapters, pp. 339-412. National Bureau of Economic Research, Inc.

OECD (2004): "Employment Outcome," Discussion paper.

Thomas, C., And F. Zanetti (2008): "Labor market reform and price stability: an application to the Euro Area," Banco de España Working Papers 0818, Banco de España.

Trefler, D. (2004): "The Long and Short of the Canada-U. S. Free Trade Agreement," American Economic Review, 94(4), 870-895.

Wacziarg, R., and J. S. Wallack (2004): "Trade liberalization and intersectoral labor movements," Journal of International Economics, 64(2), 411-439.

Woodford, M. (2003): "Interest and Prices: Foundations of a Theory of Monetary Policy," .

Zlate, A. (2010): "Offshore production and business cycle dynamics with heterogeneous firms," Discussion paper. 


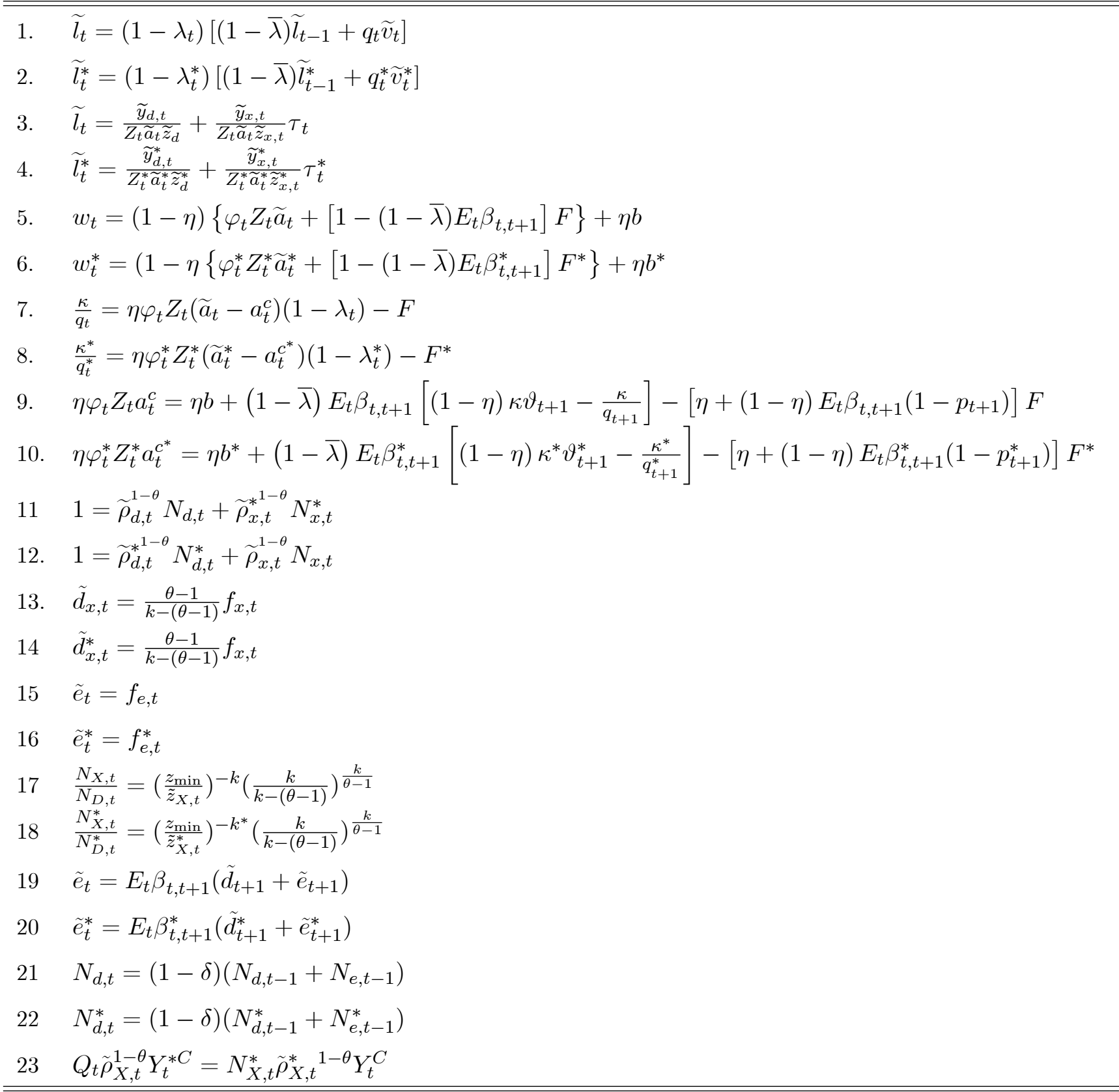

Note: $\widetilde{l}_{t}, \widetilde{v}_{t}, \bar{w}_{t}, \varphi_{t}, N_{d, t}, N_{x, t}, N_{e, t}, a_{t}^{c}, \tilde{e}_{t}, C_{t}, \widetilde{z}_{x, t}$ (and their foreign counterparts) together with $Q_{t}$ are the 23 endogenous variables determined by these equations. The other variables are defined in the text. 


\begin{tabular}{llll}
\hline \hline & Parameter & Value & Source \\
\cline { 2 - 4 } Risk aversion & $\gamma$ & 2 & Literature \\
Variety elasticity of substitution & $\theta$ & 3.8 & Literature \\
Discount factor & $\beta$ & .99 & Literature \\
Entry cost & $f_{r}$ & 4.68 & Data \\
Export cost & $f_{x}$ & .011 & $\frac{N_{x}}{N_{d}}=21 \%$ \\
Iceberg trade cost & $\tau$ & 1.8 & Literature \\
Pareto support & $z_{\text {min }}$ & 1 & Literature \\
Pareto shape & $\kappa$ & 3.4 & $\sigma_{\text {sales }}$ \\
Bargaining power & $\eta$ & .5 & Literature \\
Matching elasticity & $\xi$ & .5 & Literature \\
Firing costs & $F$ & 0 & Literature \\
Unemployment benefit & $b$ & .54 & Literature \\
Firm exit rate & $\delta$ & 0.11 & $\frac{J D^{P L A N T}}{J D^{T O T A L}}=20 \%$ \\
Exogenous separation & $\bar{\lambda}$ & .026 & $\underline{J D^{E X O G N O U S}}=68 \%$ \\
Home production & $h_{p}$ & 0.92 & $U=6 \%$ \\
Matching efficiency & $\chi$ & .69 & $q=70 \%$ \\
Vacancy cost & $\kappa$ & .49 & $\lambda^{\text {tot }=7 \%}$ \\
\hline \hline
\end{tabular}


TABLE 3: BUSINESS CYCLE STATISTICS

\begin{tabular}{lcccccccccc}
\hline \hline \multirow{2}{*}{ Variable $X$} & \multicolumn{3}{c}{$\sigma_{X}$} & \multicolumn{4}{c}{$\sigma_{X} / \sigma_{Y}$} & \multicolumn{3}{c}{$\operatorname{corr}\left(X_{R, t}, Y_{R, t}\right)$} \\
\hline$Y_{R}$ & $\mathbf{1 . 7 6}$ & 1.63 & 1.54 & $\mathbf{1}$ & 1 & 1 & $\mathbf{1}$ & 1 & 1 \\
$C_{R}$ & $\mathbf{1 . 2 0}$ & 1.32 & 1.13 & $\mathbf{0 . 6 8}$ & 0.84 & 0.73 & $\mathbf{0 . 7 4}$ & 0.98 & 0.96 \\
$I_{R}$ & $\mathbf{5 . 3 8}$ & 5.02 & 6.45 & $\mathbf{3 . 0 5}$ & 3.17 & 4.10 & $\mathbf{0 . 8 9}$ & 0.90 & 0.85 \\
$L$ & $\mathbf{0 . 9 1}$ & 0.66 & 0.67 & $\mathbf{0 . 4 2}$ & 0.42 & 0.42 & $\mathbf{0 . 7 7}$ & 0.98 & 0.98 \\
$J C$ & $\mathbf{2 . 1 1}$ & 3.27 & 3.33 & $\mathbf{1 . 1 9}$ & 2.07 & 2.15 & $\mathbf{0 . 4 7}$ & 0.40 & 0.47 \\
$J D$ & $\mathbf{3 . 1 0}$ & 5.20 & 5.28 & $\mathbf{1 . 7 6}$ & 3.29 & 3.41 & $\mathbf{- 0 . 4 6}$ & -0.61 & -0.62 \\
\hline $\operatorname{corr}(J C, J D)$ & $\mathbf{- 0 . 3 6}$ & -0.30 & -.36 & & & & & & \\
$\operatorname{corr}\left(C_{R, t}, C_{R, t}^{*}\right)$ & $\mathbf{0 . 4 4}$ & 0.30 & 0.79 & & & & & & \\
$\operatorname{corr}\left(Y_{R, t}, Y_{R, t}^{*}\right)$ & $\mathbf{0 . 5 1}$ & 0.31 & 0.45 & & & & & & \\
\hline \hline
\end{tabular}

Note: bold fonts denote data moments, normal fonts denote moments for the Baxter productivity process, and italics denote the BKK calibration

TABLE 4: BUSINESS CYCLE - ASYMMETRIC LABOR MARKETS

\begin{tabular}{lcccc}
\hline \hline \multirow{2}{*}{ Variable $X$} & \multicolumn{2}{c}{$\sigma_{X}-$ Baxter } & \multicolumn{2}{c}{$\sigma_{X}-\mathrm{BKK}$} \\
\hline & Flexible & Rigid & Flexible & Rigid \\
$Y_{R}$ & 1.63 & 1.47 & 1.54 & 1.39 \\
$L$ & 0.69 & 0.60 & 0.65 & 0.56 \\
$J C$ & 0.35 & 0.55 & 0.33 & 0.51 \\
$J D$ & 0.54 & 0.03 & .52 & 0.022 \\
$J R$ & -0.09 & 0.24 & -0.07 & 0.028 \\
\hline $\operatorname{corr}\left(C_{R, t}, C_{R, t}^{*}\right)$ & 0.30 & \multicolumn{2}{c}{0.80} \\
$\operatorname{corr}\left(Y_{R, t}, Y_{R, t}^{*}\right)$ & 0.30 & \multicolumn{3}{c}{0.45} \\
\hline \hline
\end{tabular}




\begin{tabular}{lccc}
\multicolumn{3}{c}{ TABLE 5: TRADE INTEGRATION - LONG RUN } \\
\hline \hline$\Delta \% \tau=20 \%$ & Symmetric & \multicolumn{2}{c}{ Asymmetric } \\
\hline \multirow{2}{*}{ Flex } & Flex & Rigid \\
$\% \Delta$ Welfare & 8.40 & 8.33 & 7.01 \\
$\% \Delta$ Unemployment & -1.28 & -1.26 & -0.21 \\
$\% \Delta$ TFP & 2.84 & 2.86 & 3.69 \\
$\% \Delta$ Wage & 7.84 & 7.70 & 6.12 \\
\hline \hline
\end{tabular}

TABLE 6: TRADE INTEGRATION AND BUSINESS CYCLE

\begin{tabular}{|c|c|c|c|c|c|c|}
\hline & $\tau_{o}=1.7$ & $(\Delta \tau=$ & $20 \%)$ & $\tau_{o}=2.5$ & $(\Delta \tau=$ & $8 \%)$ \\
\hline \multirow{3}{*}{$\% \Delta \operatorname{corr}\left(Y_{R, t}, Y_{R, t}^{*}\right)$} & Symmetric & Asyn & netric & Symmetric & Asyn & netric \\
\hline & \multirow{2}{*}{30.52} & \multicolumn{2}{|c|}{28.4} & 21.37 & \multicolumn{2}{|c|}{21.17} \\
\hline & & Flex & Rigid & & Flex & Rigid \\
\hline$\% \Delta \sigma_{Y_{R, t}}$ & -5.4 & -5.8 & 1.51 & -5.98 & -6.4 & 3.28 \\
\hline
\end{tabular}




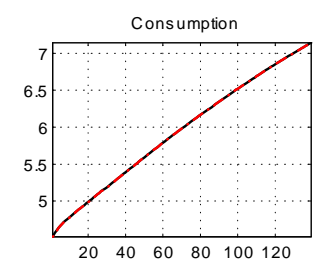

Unemployment
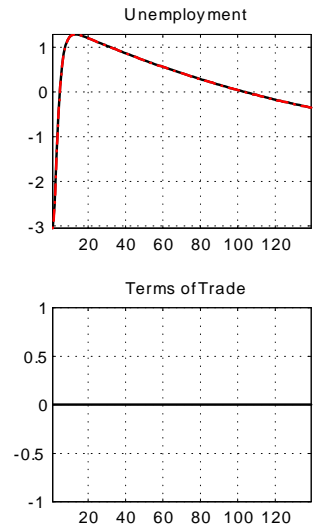

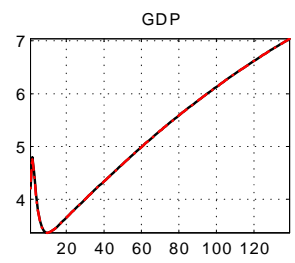

Domestic Labor
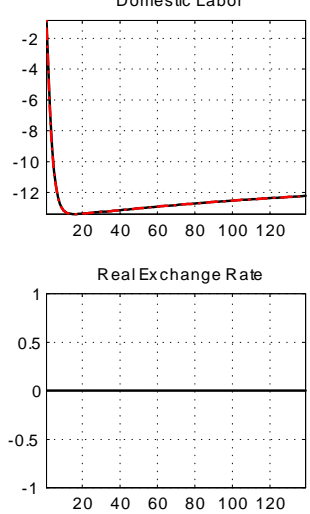

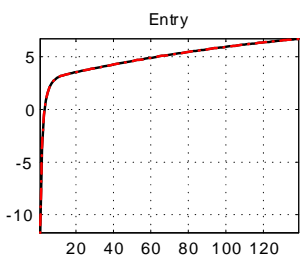

ExportLabor
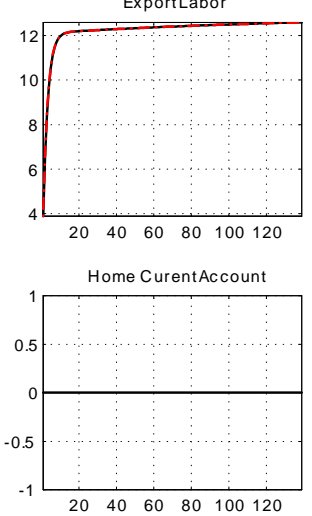
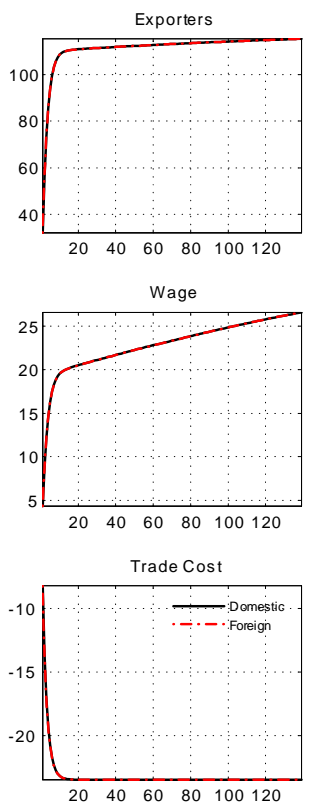

Figure 1. Symmetric Trade Integration Shock. Variables are in percentage deviations from the steady state. The unemployment rate is in deviations from the steady state.
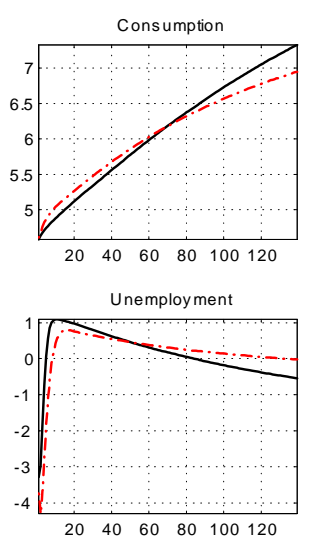

Terms of Trade

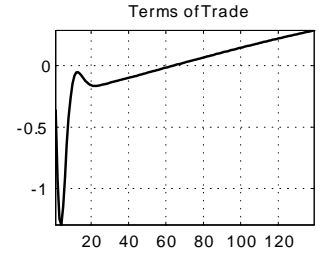

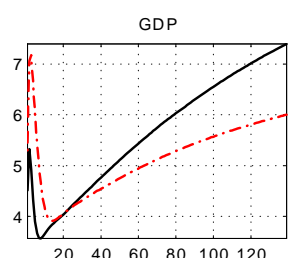
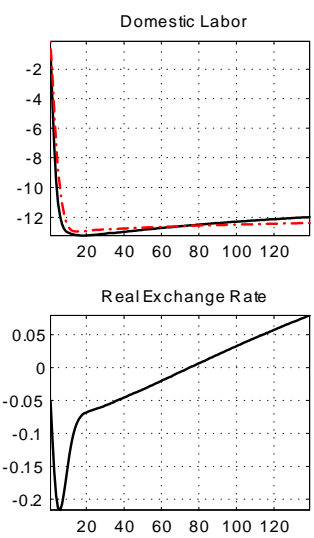

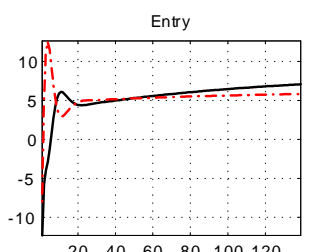

$20 \quad 40 \quad 60 \quad 80 \quad 100120$
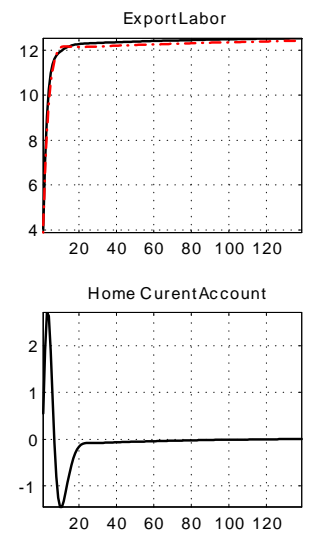
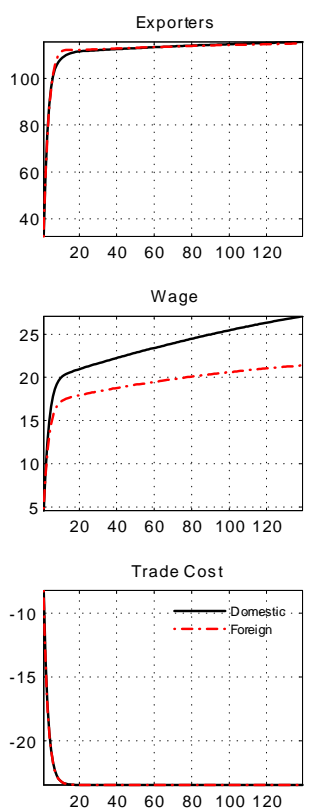

Figure 2. Trade integration shock, asymmetric labor markets. Variables are in percentage deviations from the steady state. The unemployment rate is in deviations from the steady state. 

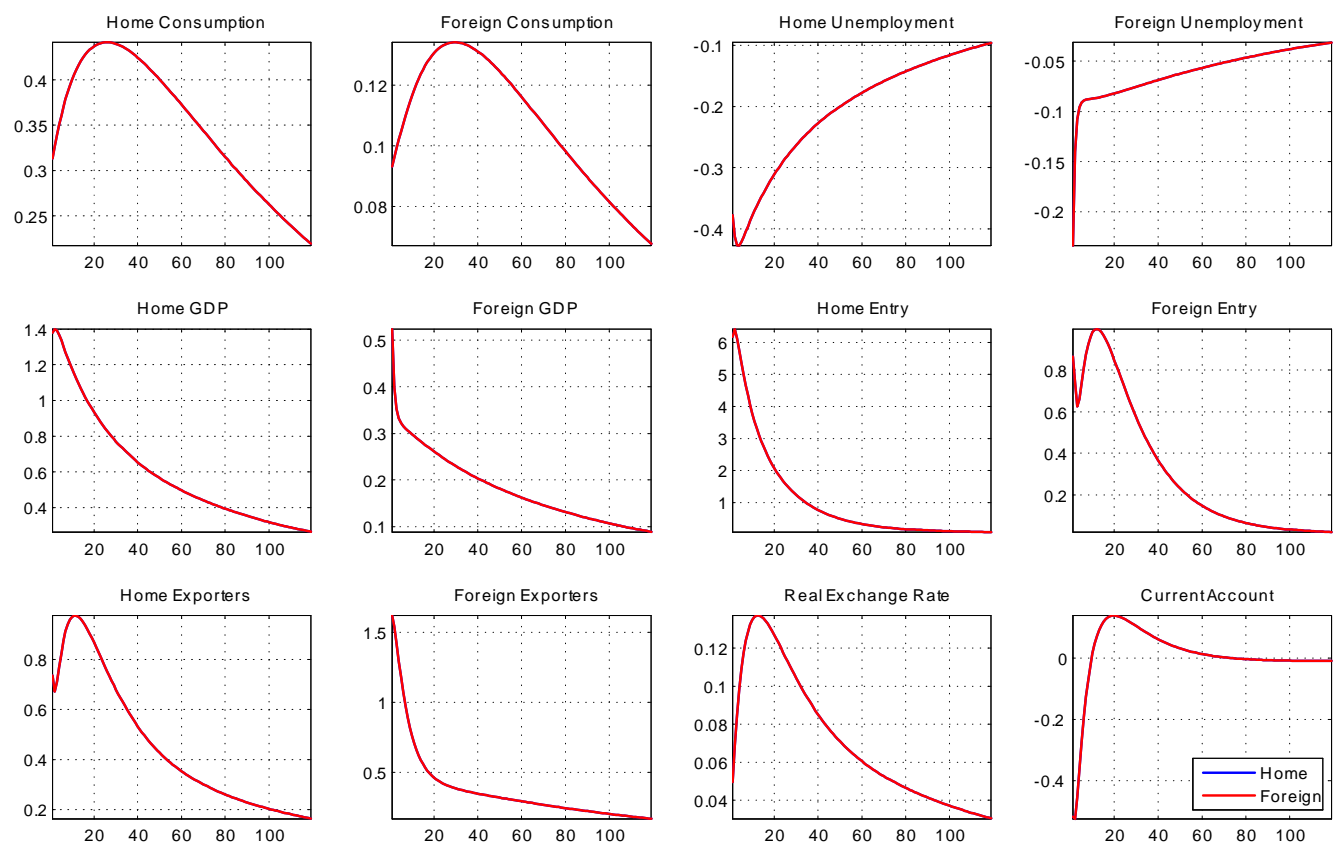

Figure 3. Home productivity shock. Variables are in percentage deviations from the steady state.

The unemployment rate is in deviations from the steady state.
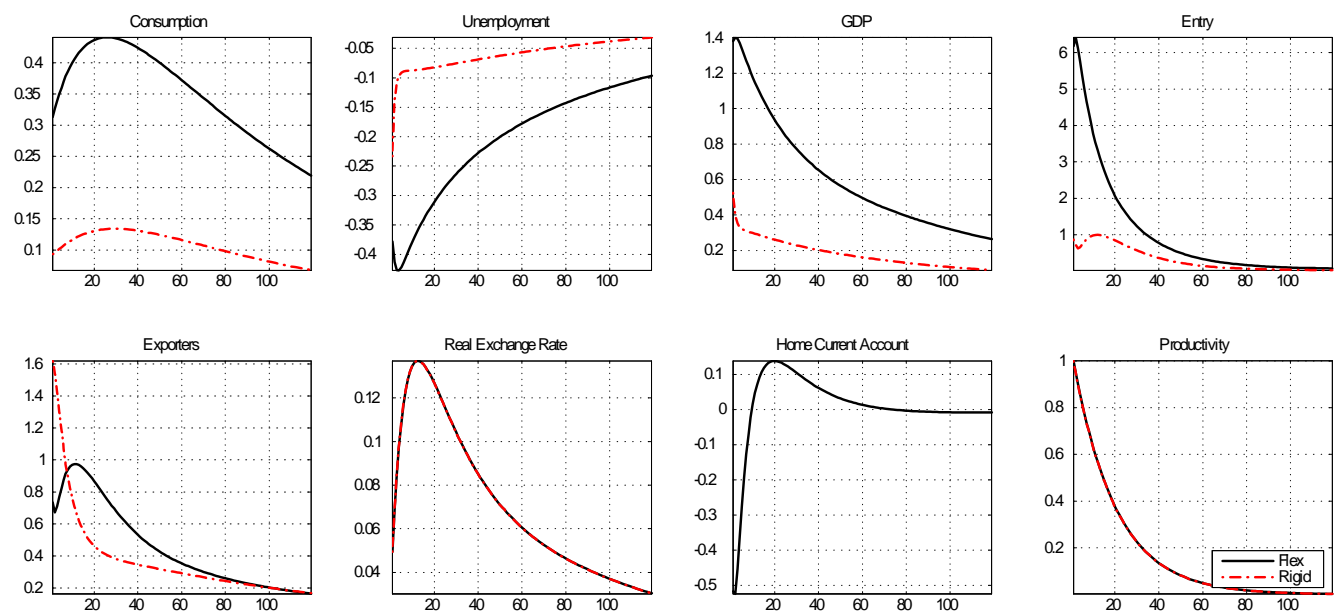

Figure 4. Global productivity shock with asymmetric labor markets. Variables are in percentage deviations from the steady state. The unemployment rate is in deviations from the steady state. 


\section{Appendix}

\section{A Wage Equation}

I assume Nash bargaining between each firm and each worker. Without loss of generality consider a worker with idiosyncratic productivity $a$ and a domestic producer with productivity $z$. The bargaining solution splits the surplus of their match in shares determined by an exogenous bargaining weight $\eta$. The sharing rule is such that:

$$
(1-\eta) S_{z, t}^{F}(a)=\eta S_{z, t}^{W}(a)
$$

where $S_{z, t}^{F}(a)$ is the value of the match for the firm and $S_{z, t}^{W}(a)$ represents the worker's surplus from the job. The outside option for the firm in wage negotiations is firing the worker and pay firing costs. Thus, the firm's surplus equals $S_{z, t}^{F}(a)=\Gamma_{z, t}(a)+F$ (see Mortensen and Pissarides, 2003), where $\Gamma_{z, t}(a)$ is the value of the job for the firm :

$$
\Gamma_{z, t}(a)=\varphi_{z, t} z Z_{t} a_{t}+(1-\bar{\lambda}) E_{t}\left[\beta_{t, t+1}\left(\widetilde{\Gamma}_{z, t+1}\left(1-\lambda_{z, t+1}\right)-\lambda_{z, t+1} F\right)\right]+w_{z, t}(a)
$$

The term $\widetilde{\Gamma}_{z, t}=\int_{a_{z, t}^{c}}^{\infty} \Gamma_{z, t}(a) d H(a) /\left(1-\lambda_{z, t}\right)$ corresponds to the Lagrange multiplier associated to the output constraint in the firm cost minimization problem and it represents the average marginal value of a match for the producer. The value of a job, $\Gamma_{z, t}(a)$, depends on the per-period real revenue generated by the match, augmented by its discounted continuation value, net of the wage bill. Using equation (4) in the text, we have:

$$
S_{z, t}^{F}(a)=\varphi_{z, t} z Z_{t} a_{t}+(1-\bar{\lambda}) E_{t} \frac{\kappa}{q_{t+1}}+F-w_{z, t}(a)
$$

The surplus of the worker is given by:

$$
S_{z, t}^{W}(a)=w_{z, t}(a)-\varpi_{t}+(1-\bar{\lambda}) E_{t} \beta_{t, t+1} \widetilde{S}_{z, t+1}^{W}
$$

where $\widetilde{S}_{z, t}^{W}=\int_{a_{z, t}^{c}}^{\infty} S_{z, t}(a) d H(a) /\left(1-\lambda_{z, t}\right)$ is the average surplus accruing to the worker when em- 
ployed in a firm with productivity $z$ and $\varpi_{t}$ is the worker outside option, defined as:

$$
\varpi_{t}=h_{p}+b+(1-\bar{\lambda}) E_{t} \beta_{t, t+1} p_{t+1} \int_{z_{\min }}^{\infty} \frac{v_{z, t+1}}{V_{t+1}} \widetilde{S}_{z, t+1}^{W} d G(z)
$$

Since the surplus-sharing rule holds in every period, I can write the average worker's surplus in firm $z$ as:

$$
\widetilde{S}_{z, t}^{W}=\frac{1-\eta}{\eta}\left[\widetilde{\Gamma}_{z, t}\left(1-\lambda_{z, t}\right)+F\left(1-\lambda_{z, t}\right)\right]
$$

From equation (4) we have that:

$$
\left(1-\lambda_{z, t}\right) \widetilde{\Gamma}_{z, t}=\frac{\kappa}{q_{t}}+\lambda_{z, t} F
$$

which implies:

$$
\widetilde{S}_{z, t}^{W}=\frac{1-\eta}{\eta}\left[\frac{\kappa}{q_{t}}+F\right]
$$

Inserting the definitions of workers surplus into the sharing rule (25) I obtain:

$$
(1-\eta)\left[\varphi_{z, t} z Z_{t} a_{t}-w_{z, t}(a)+(1-\bar{\lambda}) E_{t} \frac{\kappa}{q_{t+1}}+F\right]=\eta\left[w_{z, t}(a)-\varpi_{t}\right]+(1-\eta)(1-\bar{\lambda}) E_{t}\left[\beta_{t, t+1}\left(\frac{\kappa}{q_{t+1}}+F\right)\right]
$$

The above expression implies that the wage of a worker with productivity a employed in firm $z$ is equal to:

$$
w_{z, t}(a)=(1-\eta)\left\{\varphi_{z, t} z Z_{t} a_{t}+\left[1-(1-\bar{\lambda}) E_{t} \beta_{t, t+1}\right] F\right\}+\eta \varpi_{t}
$$

Thus, the wage differential between a generic worker $a$ and the marginal worker $a_{t}^{c}$ is given by:

$$
w_{z, t}(a)-w_{z, t}\left(a_{z, t}^{c}\right)=(1-\eta) \varphi_{z, t} z Z_{t}\left(a-a_{z, t}^{c}\right)
$$

\section{B Symmetry in Wages and Job Destruction Cut-off}

Here I show that each incumbent has the same marginal workers regardless of the specific productivity $z$ and that all firms pay the same average wage $\widetilde{w}_{t}$. Combining the job creation equation (7) and equation (27), we have:

$$
\frac{\kappa}{q_{t}}=\eta \varphi_{z, t} z Z_{t} \int_{a_{z, t}^{c}}^{\infty}\left(a-a_{z, t}^{c}\right) d H(a)-F
$$


Equation (28) can be restated as:

$$
\varphi_{z, t} z \int_{a_{z, t}^{c}}^{\infty}\left(a-a_{t}^{c}\right) d H(a)=\Lambda_{t}^{J C} .
$$

where $\Lambda_{t}^{J C} \equiv\left(\kappa / \eta q_{t} Z_{t}\right)+F$ only includes aggregate variables, i.e. $\Lambda_{t}^{J C}$ does not depend of the firm's specific productivity $z$. Then combine the job destruction equation (8) with equation (26) evaluated at the cut-off productivity $a_{t}^{c}$ to obtain:

$$
\varphi_{z, t} z a_{z, t}^{c}=\Lambda_{t}^{J D}
$$

where $\Lambda_{t}^{J D} \equiv\left(1 / \eta Z_{t}\right)\left[(1-\eta)\left(1-(1-\bar{\lambda}) E_{t} \beta_{t, t+1}\right) F+\eta \varpi_{t}-E_{t}\left(\beta_{t, t+1} \kappa / q_{t+1}\right)\right]$ also depends on aggregate variables. From (30) we have that:

$$
\varphi_{z, t} z=\frac{\Lambda_{t}^{J D}}{a_{z, t}^{c}}
$$

Plugging equation (31) into equation (29), I obtain:

$$
\frac{1}{a_{z, t}^{c}} \int_{z, t}^{c}\left(a-a_{z, t}^{c}\right) d H(a)=\frac{\Lambda_{t}^{J C}}{\Lambda_{t}^{J D}}
$$

where the right hand side only depends on aggregate variables. Define $F\left(a_{z, t}^{c}\right) \equiv\left(1 / a_{z, t}^{c}\right) \int_{a_{z, t}^{c}}^{\infty}(a-$ $\left.a_{z, t}^{c}\right) d H(a)$. I now show that $a_{z, t}^{c}=a_{t}^{c}$ is the only solution to

$$
F\left(a_{z, t}^{c}\right)=\frac{\Lambda_{t}^{J C}}{\Lambda_{t}^{J D}}
$$

To do so it is enough to show that $F\left(a_{z, t}^{c}\right)$ is monotonic in $a_{z, t}^{c}$ Applying the Leibniz rule, we have that:

$$
\frac{d F\left(a_{z, t}^{c}\right)}{a_{z, t}^{c}}=-\left(\frac{1}{a_{z, t}^{c}}\right)^{2}-G\left(a_{z, t}^{c}\right)<0 .
$$

Since $a_{z, t}^{c}=a_{t}^{c}$, it follows that $\varphi_{z, t} z=\Lambda_{t}^{J D} / a_{t}^{c}$. Defining $\varphi_{t} \equiv \Lambda_{t}^{J D} / a_{t}^{c}$, firm $z$ marginal cost is given by:

$$
\varphi_{z, t}=\frac{\varphi_{t}}{z}
$$

From equation (26) we have that $a_{z, t}^{c}=a_{t}^{c}$ together with $\varphi_{z, t}=\frac{\varphi_{t}}{z}$ imply that $w_{z, t}(a) \equiv w_{t}(a)$ : 
each worker with productivity $a$ receives the same wage regardless of the firm specific productivity:

$$
w_{z, t}(a) \equiv w_{t}(a)=(1-\eta)\left\{\varphi_{t} Z_{t} a_{t}+(1-\bar{\lambda}) E_{t} \beta_{t, t+1} \kappa \vartheta_{t+1}+\left[1-(1-\bar{\lambda}) E_{t} \beta_{t, t+1}\right] F\right\}+\eta \varpi_{t} .
$$

It follows that all firms pay the same average wage, i.e. $\widetilde{w}_{z, t} \equiv \widetilde{w}_{t}$. Finally, if the wage rate is independent on firm characteristics, equation (24) implies that $\widetilde{S}_{z, t}^{W} \equiv \widetilde{S}_{t}^{W}$. Hence, the worker's outside option becomes:

$$
\begin{aligned}
\varpi_{t} & =h_{p}+b+(1-\bar{\lambda}) E_{t}\left(\beta_{t, t+1} p_{t+1} \widetilde{S}_{t+1}^{W}\right)= \\
& =h_{p}+b+(1-\bar{\lambda}) \frac{1-\eta}{\eta} E_{t}\left[\beta_{t, t+1}\left(\kappa \vartheta_{t+1}+p_{t+1} F\right)\right] .
\end{aligned}
$$

Using the equilibrium value of $\varpi_{t}$, the average wage becomes:

$$
\widetilde{w}_{t}=(1-\eta)\left\{\varphi_{t} Z_{t} \widetilde{a}_{t}+(1-\bar{\lambda}) E_{t} \beta_{t, t+1}\left[1-(1-\bar{\lambda}) E_{t}\left(1-p_{t+1}\right) \beta_{t, t+1}\right] F\right\}+\eta\left(h_{p}+b\right),
$$

which is the expression presented in the text.

\section{Symmetry Between Incumbents with Productivity z}

Here I show that, upon entry, a new producer with productivity $z$ post vacancies to match the end-of-period size of all the incumbents that have the same productivity level $z$. The result stems from the fact that new producers correctly anticipate that when they will start production their marginal cost will be identical to the marginal costs of incumbents with the same productivity $z$. As a result, the dynamic problem that a newly created firm solves when it begins production is identical to the problem solved by all the other incumbents.

Without loss of generality, consider incumbents and new entrants with productivity $z$. First notice that each firm with technology $z$ has the same marginal cost $\varphi_{z, t}$. To see this it is enough to rewrite (30) as $\varphi_{z, t}=\Lambda_{t}^{J D} / z a_{t}^{c}$. Once again the result follows from the fact that $a_{t}^{c}$ and the wage rate are identical across producers. Then, if all the producing firm with relative technology $z$ have the same marginal cost $\varphi_{z, t}$ it must be that any producing firm $z$ has the same stock of labor. To see this, notice that if $\varphi_{z, t}$ is identical among $z$-firms, then all of them are charging the same domestic relative price $\rho_{d, t}(z)$ and - if exporting - the same export price $\rho_{x, t}(z) .{ }^{39}$ It follows

\footnotetext{
${ }^{39}$ This follows from the fact that $\rho_{d, t}(z)=(\theta /(\theta-1)) \varphi_{z, t}$ and $\rho_{x, t}(z)=\left(\tau_{t} \rho_{d, t}(z)\right) / Q_{t}$.
} 
that each producer with productivity $z$ faces the same domestic and foreign demand schedules since $y_{d, t}(z)=(1-\alpha) \rho_{d, t}^{-\phi}(z)\left(P_{d, t} / P_{t}\right)^{\frac{\theta-\phi}{1-\theta}} Y_{t}$ and $y_{x, t}(z)=(1-\alpha) \rho_{x, t}^{-\phi}(z)\left(P_{x, t} / P_{t}^{*}\right)^{\frac{\theta-\phi}{1-\theta}} Y_{t}^{*}$. But this implies that:

$$
l_{d, t}(z)=\frac{y_{d, t}(z)}{z Z_{t} \widetilde{a}_{t}} \quad \text { and } l_{x, t}(z)=\frac{y_{x, t}(z)}{z Z_{t} \widetilde{a}_{t}}
$$

which implies that each firm with productivity $z$ producing at time $t$ has the same stock of labor, regardless of when it entered the market.

\section{Steady State Analysis}

\section{Unemployment Rate}

To find an expression for steady state unemployment, notice that total employment $L_{t} \equiv\left(N_{t}+N_{e, t}\right) \widetilde{l}_{t}$ can be written as $L_{t}=L_{t}^{I}+L_{t}^{E}$ where $L_{t}^{I}=N_{t} \widetilde{l}_{t}$ is the stock of labor of incumbents and $L_{t}^{E}=N_{e, t} \widetilde{l}_{t}=\left(N_{e, t} / N_{t}\right) L_{t}^{I}$ is the stock of labor of new entrants. Using equation (1) we have:

$$
L_{t}^{I}=\left(1-\lambda_{t}\right)\left[(1-\bar{\lambda}) \frac{N_{t}}{N_{t-1}} L_{t-1}^{I}+q_{t} V_{t}^{I}\right]
$$

where $V_{t}^{I}=N_{t} \widetilde{v}_{t}$.

Since $L_{t}=L_{t}^{I}\left(1+N_{e, t} / N_{t}\right)$ then $L_{t}$ can then be written as:

$$
L_{t}=\left(1-\lambda_{t}\right)\left[(1-\bar{\lambda})\left[\frac{N_{t}}{N_{t-1}}\left(1+\frac{N_{e, t}}{N_{t-1}}\right)\right] L_{t-1}^{I}+q_{t}\left(1+\frac{N_{e, t}}{N_{t}}\right) V_{t}^{I}\right]
$$

Each new entrant post on average $\widetilde{l}_{t} /\left[\left(1-\lambda_{t}\right) q_{t}\right]$ vacancies. Hence the total number of vacancies posted by newly created firms is given by $V_{t}^{E} \equiv N_{e, t} \widetilde{l}_{t} /\left[\left(1-\lambda_{t}\right) q_{t}\right]$. Recall that $\widetilde{l}_{t} /\left(1-\lambda_{t}\right)=$ $\widetilde{l}_{t-1}+q_{t} \widetilde{v}_{t}$. It follows that:

$$
V_{t}^{E}=\frac{N_{e, t}}{N_{t-1}} \frac{L_{t}^{I}}{q_{t}}+N_{e, t} \frac{V_{t}^{I}}{N_{t}}
$$

Using equation (33), we can substitute out $q_{t}\left(N_{e, t} / N_{t}\right) V_{t}^{I}$ from equation (32). Also, making use of the fact that $V_{t}=V_{t}^{I}+V_{t}^{E}$ we have:

$$
L_{t}=\left(1-\lambda_{t}\right)\left[(1-\bar{\lambda}) \frac{N_{t}}{N_{t-1}}\left(\frac{N_{t}}{N_{t}+N_{e, t}}\right) L_{t-1}+q_{t} V_{t}\right]
$$


Notice that in steady state $\frac{N}{N+N_{e}}=1-\delta$. Hence the steady-state version of equation (34) implies:

$$
M=\frac{1-(1-\lambda)(1-\bar{\lambda})(1-\delta)}{(1-\lambda)} L
$$

where $M=q V$ is the aggregate number of matches. Moreover, since $p=M / U, p=\chi \vartheta_{t}^{1-\varepsilon}$ and $L=(1-U) /[(1-\bar{\lambda})(1-\delta)]$, we obtain:

$$
U=\frac{\Lambda\left(a^{c}\right)}{\chi \vartheta_{t}^{1-\varepsilon}+\Lambda\left(a^{c}\right)},
$$

where $\Lambda\left(a^{c}\right)=\frac{1-(1-\lambda)(1-\bar{\lambda})(1-\delta)}{(1-\lambda)(1-\bar{\lambda})(1-\delta)}=\frac{1}{(1-\lambda)(1-\bar{\lambda})(1-\delta)}-1$.

\section{Marginal revenue}

First notice that symmetry implies that $Q=1, \widetilde{\rho}_{x}=\widetilde{\rho}_{x}^{*}$. and $N_{x}=N_{x}^{*}$. Moreover, equation (19) can be combined with the pricing equations that determine $\widetilde{\rho}_{d, t}$ and $\widetilde{\rho}_{x, t}$ to derive an expression for $\varphi$ : It follows that equation (19) becomes:

$$
\begin{aligned}
1 & =\widetilde{\rho}_{d}^{1-\theta} N_{d}+\widetilde{\rho}_{x}^{1-\theta} N_{x}= \\
& =\left(\frac{\varphi}{\mu}\right)^{1-\theta} N_{d, t}\left[\widetilde{z}_{d}^{\theta-1}+\left(\frac{\widetilde{z}_{x}}{\tau}\right)^{\theta-1} \frac{N_{x}}{N_{d}}\right],
\end{aligned}
$$

where $\mu=(\theta-1) \theta$. From the definition of the average productivity $\tilde{z}$, we have that $\tilde{z}^{\theta-1}=$ $\left[\widetilde{z}_{d}^{\theta-1}+\left(\frac{\widetilde{z}_{x}}{\tau}\right)^{\theta-1} \frac{N_{x}}{N_{d}}\right]$. Hence:

$$
\left(\frac{\varphi}{\mu}\right)^{\theta-1}=N_{d, t} \tilde{z}^{\theta-1}
$$

which implies:

$$
\varphi=\mu N_{d, t}^{\frac{1}{\theta-1}} \tilde{z}
$$

When countries have asymmetric labor markets instead, it is no longer the case that $Q=1, \widetilde{\rho}_{x}=\widetilde{\rho}_{x}^{*}$. and $N_{x}=N_{x}^{*}$. Thus we have $\widetilde{\rho}_{d}^{1-\theta} N_{d}=1-\widetilde{\rho}_{x}^{*^{1-\theta}} N_{x}^{*}$. It follows that:

$$
\begin{aligned}
\varphi & =\mu \widetilde{z}_{d}\left(\frac{1-\widetilde{\rho}_{x}^{*^{1-\theta}} N_{x}^{*}}{N_{d}}\right)^{\frac{1}{1-\theta}}= \\
& =\mu N_{d}^{\frac{1}{\theta-1}} \tilde{z} \Phi
\end{aligned}
$$


where $\Phi=\left(1-\widetilde{\rho}_{x}^{*^{1-\theta}} N_{x}^{*}\right)^{\frac{1}{1-\theta}} \widetilde{z}_{d} / \tilde{z}$. 